OPEN ACCESS

Edited by:

Zhaogang Teng,

Nanjing University of Posts and

Telecommunications, China

Reviewed by:

Andrea Angeli,

University of Florence, Italy

Ajay Sharma,

University of Texas Health Science Center at Houston, United States

*Correspondence:

Feng Gao

rggaofeng@sdu.edu.cn

${ }^{+}$These authors have contributed equally to this work

Specialty section:

This article was submitted to Pharmacology of Anti-Cancer Drugs,

a section of the journal

Frontiers in Pharmacology

Received: 30 January 2021

Accepted: 19 May 2021

Published: 11 June 2021

Citation:

Liang T, Sun X, Li W, Hou G and Gao F (2021) 1,2,3-Triazole-Containing

Compounds as Anti-Lung Cancer Agents: Current Developments, Mechanisms of Action, and Structure-Activity Relationship. Front. Pharmacol. 12:661173. doi: 10.3389/fphar.2021.661173

\section{1,2,3-Triazole-Containing Compounds as Anti-Lung Cancer Agents: Current Developments, Mechanisms of Action, and Structure-Activity Relationship}

\author{
Ting Liang ${ }^{1 \dagger}$, Xiangyang Sun ${ }^{2 \dagger}$, Wenhong $\mathrm{Li}^{3}$, Guihua Hou ${ }^{1}$ and Feng Gao ${ }^{1 *}$ \\ ${ }^{1}$ Key Laboratory for Experimental Teratology of the Ministry of Education and Biomedical Isotope Research Center, School of \\ Basic Medical Sciences, Cheeloo College of Medicine, Shandong University, Jinan, China, ${ }^{2}$ Department of Interventional \\ Radiology, Qilu Hospital of Shandong University, Jinan, China, ${ }^{3}$ Department of Oncology, Shandong Provincial Hospital Affiliated \\ to Shandong First Medical University, Jinan, China
}

Lung cancer is the most common malignancy and leads to around one-quarter of all cancer deaths. Great advances have been achieved in the treatment of lung cancer with novel anticancer agents and improved technology. However, morbidity and mortality rates remain extremely high, calling for an urgent need to develop novel anti-lung cancer agents. 1,2,3-Triazole could be readily interact with diverse enzymes and receptors in organisms through weak interaction. 1,2,3-Triazole can not only be acted as a linker to tether different pharmacophores but also serve as a pharmacophore. This review aims to summarize the recent advances in 1,2,3-triazole-containing compounds with anti-lung cancer potential, and their structure-activity relationship (SAR) together with mechanisms of action is also discussed to pave the way for the further rational development of novel anti-lung cancer candidates.

Keywords: hybrid molecules, lung cancer, anticancer, structure-activity relationship, triazole

\section{INTRODUCTION}

Lung cancer has high morbidity and represents the leading cause of cancer-related deaths (around 20\% of all mortalities in cancer) (Nasim et al., 2019; Willis et al., 2019; Bade and Dela Cruz, 2020; Majem et al., 2020; Salehi et al., 2020; Zhang et al., 2020). With the development of novel anticancer agents and improvement of technology, lung cancer treatment has achieved great progress in recent decades, but the morbidity and mortality rates remain high and the overall 5-year survival rate is only around 15\% (Gray et al., 2019; Coakley and Popat, 2020).

1,2,3-Triazole moiety (Figure 1), a major pharmacophore system among nitrogencontaining heterocycles, can be obtained readily using "click" chemistry with copper- or ruthenium-catalyzed azide-alkyne cycloaddition reactions and it can also act as a linker to tether different pharmacophores. Moreover, 1,2,3-triazole could form diverse non-covalent interactions, such as hydrogen bonds, van der Waals forces, and dipole-dipole bonds with various enzymes, proteins, and receptors (Bonandi et al., 2017; Bozorov et al., 2019). Hence, 1,2,3-triazole derivatives exhibit a variety of promising biological properties, including antibacterial (Zhang, 2019; Xu, 2020), antimalarial (Chu et al., 2019; Feng et al., 2020), antitubercular (Zhang et al., 2017; Yan et al., 2020), antiviral (Rani et al., 2020; Feng et al., 2021), and anticancer (Lal and Yadav, 2018; Slavova et al., 2020) activities. For example, 1,2,3- 
<smiles>NC(=O)c1nnn(Cc2cc(Cl)c(C(=O)c3ccc(Cl)cc3)c(Cl)c2)c1N</smiles>

1,2,3-triazole

carboxyamidotriazole

FIGURE 1 | Chemical structures of 1,2,3-triazole moiety and carboxyamidotriazole.

triazoles could exert the anticancer potential by inducing the cell cycle arrest and apoptosis of cancer cells. The 1,2,3triazole-containing agent carboxyamidotriazole (CAI) could synergise with sorafenib to combat NSCLC by inhibiting NANOG and aggravating apoptosis (Ferreira et al., 2013; Chen et al., 2017). These studies suggest that 1,2,3-triazole derivatives are useful scaffolds for development of novel anti-lung cancer agents with low toxicity and high efficacy.

In recent years, a variety of 1,2,3-triazole-containing compounds are designed, synthesized, and evaluated for their anti-lung cancer activity, and some of them have the potential to act on dual-/multi-targets simultaneously (Jain and Piplani, 2019; Xu et al., 2019; Farrer and Griffith, 2020; Sahu et al., 2020). This review summarizes the current developments, mechanisms of action, and structure-activity relationships (SARs) of 1,2,3-triazole-containing compounds with anti-lung cancer potential to pave the way for further rational development.

\section{1,2,3-TRIAZOLE-CONTAINING CHROMENE/COUMARIN DERIVATIVES}

Chromene (benzopyran) and coumarin (chromen-2-one) moieties are present in a large number of biologically active compounds, and their derivatives are potent inhibitors of a variety of proteins, such as EGFR, tyrosine kinase, ERK1/2, PI3K, HSP 90, Bax, STAT proteins, nuclear factor kappa-lightchain-enhancer of activated B cells (NF-kB), and telomerase associated with lung cancer (Manjinder et al., 2015; Manvendra et al., 2018; Al-Warhi et al., 2020; Oliveira-Pinto et al., 2020). Therefore, therapeutic drug candidates could be obtained by combination of 1,2,3-triazole and chromene/ coumarin for the treatment of lung cancer, even drug-resistant and multidrug-resistant (MDR) forms.

1,2,3-Triazole-containing chromene derivatives $\mathbf{1}$ (Figure 2) possess broad-spectrum activity against six human cancer cell lines, and an antiproliferative SAR study against the A549 lung cancer cell line $\left(\mathrm{IC}_{50}: 1.02-74.28 \mu \mathrm{m}\right.$, MTT assay) revealed that the fluoro atom on the phenyl ring contributes to the activity. However, 1,2,3-triazole is not crucial for the activity and replacement of 1,2,3-triazole by 1,2,4-triazole is also tolerated (Luan et al., 2020). In addition, the phenyl group at the $\mathrm{C}-2$ position of the chromene moiety has great influence on the activity, as evidenced by the decreased activity of compounds 2 ( IC $_{50}$ : $32.4-596.6 \mu \mathrm{m}$, MTT assay) against A549 cells (Wu et al., 2019). Among them, compounds $\mathbf{1 a}$,b $\left(\mathrm{IC}_{50}: 27.89 \mu \mathrm{m}\right)$, the most active against A549 cells, are less potent than the reference Chrysin $\left(\mathrm{IC}_{50}: 8.80 \mu \mathrm{m}\right)$.

1,2,3-Triazole-containing chromene derivatives 3 ( $\mathrm{IC}_{50}$ : $0.28-6.30 \mu \mathrm{m}$, MTT assay) exhibit excellent activity against

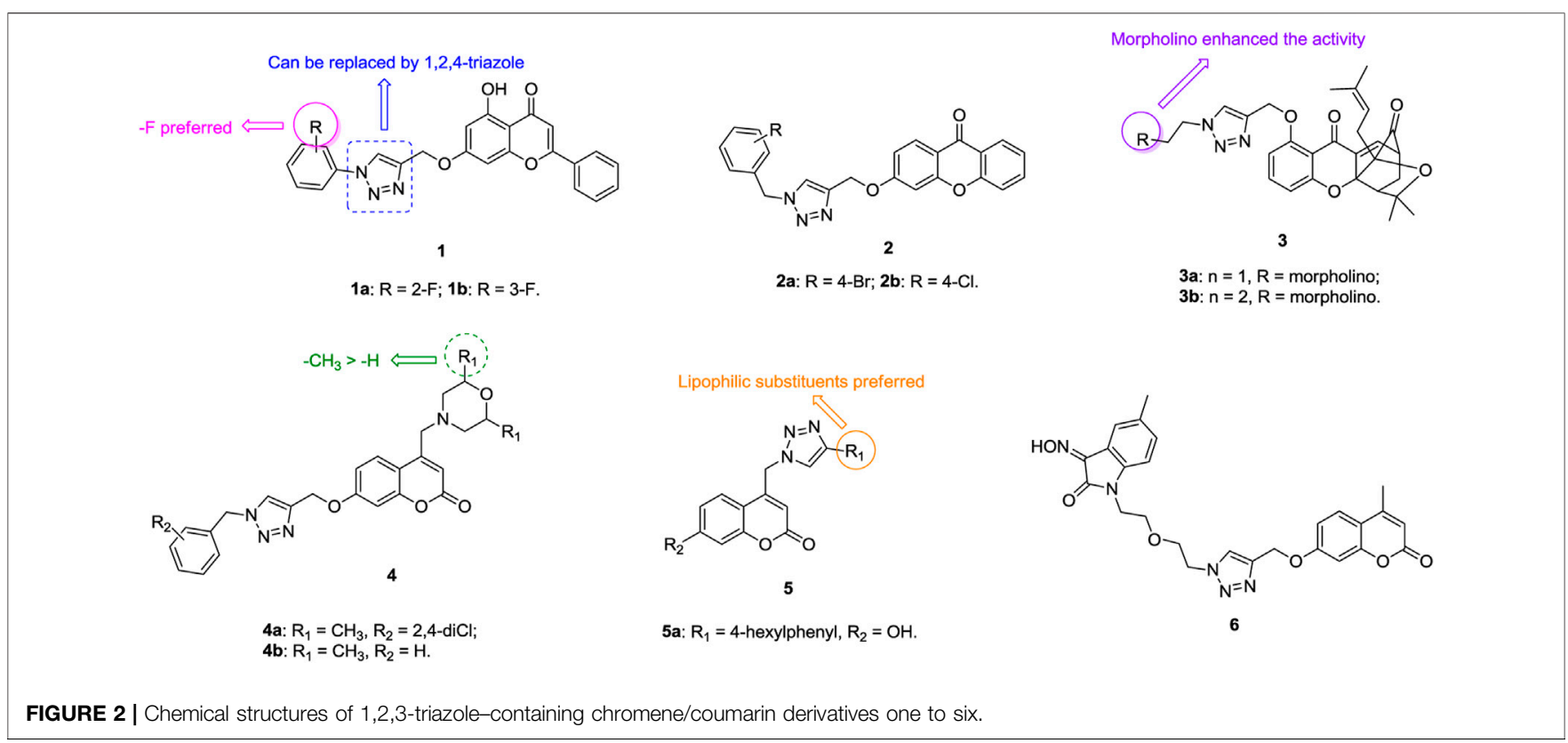


A549, taxol-resistant A549 (A549/taxol), and cisplatin-resistant A549 (A549/cisplatin) cancer cell lines, and an SAR study proved that the morpholino group at the $\mathrm{R}$ position could enhance the activity ( $\mathrm{Li}$ et al., 2017). In particular, compound 3a (DDO-6318, $\left.\mathrm{IC}_{50}: 0.31-0.42 \mu \mathrm{m}\right)$ is highly potent against A549, A549/taxol and A549/cisplatin lung cancer cell lines, and the resistance index (RI: $\left.\mathrm{IC}_{\text {resistant cells }} / \mathrm{IC}_{\text {sensitive cells }}\right)$ is approximately 1 , demonstrating its potential for the treatment of drug-sensitive and drug-resistant lung cancers. The activity of DDO-6318 is at the same level as those of DDO-6106 ( $\mathrm{IC}_{50}$ : $0.46 \mu \mathrm{m})$ and gambogic acid $\left(\mathrm{IC}_{50}: 0.29 \mu \mathrm{m}\right)$ against $\mathrm{A} 549 /$ taxol cells but is around eight times superior to those of DDO-6106 $\left(\mathrm{IC}_{50}: 0.46 \mu \mathrm{m}\right)$ and gambogic acid ( $\left.\mathrm{IC}_{50}: 0.29 \mu \mathrm{m}\right)$ against A549 and A549/cisplatin cells. In the mouse model xenografted with A549, DDO-6318 (71.32\% inhibition in tumor growth at $20 \mathrm{mg} / \mathrm{kg}$, twice daily doses/BID, and intravenous administration) displays significant inhibitory effect on the growth of inoculated A549 in mice without causing vascular irritation or weight loss, and its activity is higher than those of DDO-6101 $(34.56 \%$ inhibition at $20 \mathrm{mg} / \mathrm{kg})$ and 5-fluorouracil $(64.71 \%$ inhibition at $20 \mathrm{mg} / \mathrm{kg}$ ). Similar results were also observed when oral administraion of DDO-6318 (66.43\% inhibition at $50 \mathrm{mg} / \mathrm{kg}$ daily oral dose for DDO-6318 and $21.43 \%$ inhibition for DDO6101 at the same dose). Thus, DDO-6318 can be considered as a new and orally active natural product-like anti-lung cancer candidate for further clinical studies.

Some 1,2,3-triazole-containing coumarin derivatives $4\left(\mathrm{IC}_{50}\right.$ : $0.8-27.08 \mu \mathrm{m}$, MTT assay) are active against various cancer cell lines, and an antiproliferative SAR study against A549 cells illustrates that the methyl group at the $\mathrm{R}_{1}$ position could result in the improved activity (Liu et al., 2017; Goud et al., 2019). Among them, compounds $4 \mathbf{a}, \mathbf{b}\left(\mathrm{IC}_{50}: 2.97\right.$ and $4.78 \mu \mathrm{m}$ ) are more potent than cisplatin $\left(\mathrm{IC}_{50}: 24.15 \mu \mathrm{m}\right)$ against $\mathrm{A} 549$ cells. Moreover, compound $4 \mathbf{4 a}\left(\mathrm{IC}_{50}: 49.07 \mu \mathrm{m}\right)$ shows low cytotoxicity toward mouse embryonic fibroblast cells NIH/ $3 \mathrm{~T} 3$, and the selective index (SI: $\mathrm{IC}_{50(\mathrm{NIH}-3 \mathrm{~T} 3)} / \mathrm{IC}_{50 \text { (A549) }}$ ) is 16.5. A mechanistic study elucidated that compound $4 a$ could induce sub-G1 phase arrest, increase apoptosis, decrease the mitochondrial membrane potential, and promote reactive oxygen species (ROS) production. 1,2,3Triazole-containing coumarin derivatives $5 \quad\left(\mathrm{IC}_{50}: \quad 8.73-\right.$ $>100 \mu \mathrm{m}$, MTT assay) show weak to moderate activity against a panel of cancer cell lines, including A549 cells, and a strong correlation exists between lipophilicity profile and antiproliferative activity (Kraljevic et al., 2016). Compound 5a $\left(\mathrm{IC}_{50}: 8.87 \mu \mathrm{m}\right)$ displays the highest inhibitory activity against A549 cells, but it is toxic against normal fibroblasts WI38 ( IC $\left._{50}: 13.96 \mu \mathrm{m}\right)$.

Generally, incorporation of the third fragment, such as $\beta$-lactam (Dhawan et al., 2020) and uracil (Sanduja et al., 2020), is detrimental to the antiproliferative activity against lung cancer cells, but some 1,2,3-triazole-tethered coumarinisatin hybrids, such as compound $6\left(\mathrm{IC}_{50}: 18.67 \mu \mathrm{m}, \mathrm{SRB}\right.$ assay), show certain activity against A549 cells (Diao et al., 2019; Xu et al., 2019). Hence, these compounds still need further modification.

\section{1,2,3-TRIAZOLE-CONTAINING CHALCONE DERIVATIVES}

Chalcones are scaffolds that appear as an important structural component in various natural products and possess some useful biological properties. Chalcones are potential inhibitors of aromatase, P-glycoprotein (P-gp), histone deacetylase (HDAC), matrix metalloproteinase (MMP), NF$\kappa \mathrm{B}$, tubulin, vascular endothelial growth factor, and vascular endothelial growth factor receptor 2 (VEGFR-2) kinase; thus, chalcones are endowed with broad-spectrum antiproliferative activity against drug-susceptible and drug-resistant cancers, even MDR cancers (Karthikeyan et al., 2015; Gao et al., 2020). Accordingly, 1,2,3-triazole--containing chalcone derivatives are useful prototypes for the discovery of novel anticancer candidates.

1,2,3-Triazole-containing chalcone derivatives 7 (Figure 3, $\mathrm{IC}_{50}: 8.67-11.62 \mu \mathrm{M}, \mathrm{MTT}$ assay) show potential activity against A549 cells. An SAR study illustrated that the bromo group is essential for the activity, and replacement by heterocycles results in loss of activity (Vanaparthi et al., 2020). Among them, compounds 7 a,c $\left(\mathrm{IC}_{50}: 8.67\right.$ and $\left.9.74 \mu \mathrm{m}\right)$ with single digital micromolar inhibitory activity are comparable to doxorubicin $\left(\mathrm{IC}_{50}: 3.24 \mu \mathrm{m}\right)$. Compounds 8 ( $\mathrm{IC}_{50}: 9-60 \mu \mathrm{m}$, MTT assay) are active against A549 cells, and a mechanistic study revealed that these compounds could exert antiproliferative activity by inducing apoptosis and G2/S arrest as well as triggering mitochondrial potential loss (Yadav et al., 2017). An SAR study demonstrated that introducing a methoxy group into the phenyl ring could not increase the activity apparently, and the activity of compounds $9\left(\mathrm{GI}_{50}: 4.7-11.9 \mu \mathrm{m}, \mathrm{SRB}\right.$ assay) is considerably inferior to that of combretastatin-A4 $\left(\mathrm{GI}_{50}\right.$ : $0.08 \mu \mathrm{m}$ ) against A549 cells (Hussaini et al., 2016). Further study proved that the benzyl group at the $\mathrm{N}-1$ position of the 1,2,3-triazole moiety is not crucial for the activity, and replacement by the phenyl ring is also permitted, as evidenced by that compounds $10 \mathbf{a}, \mathbf{b}\left(\mathrm{IC}_{50}\right.$ : 62.51 and $75.41 \mu \mathrm{m}$, MTT assay) show comparable activity to doxorubicin $\left(\mathrm{IC}_{50}: 39.86 \mu \mathrm{m}\right)$ against A549 cells (Raghavender et al., 2020). The 1,2,3triazole-containing chalcone compounds 11a-c ( $\mathrm{IC}_{50}$ : 35.81-50.82 $\mu \mathrm{m}$, MTT assay) are more potent than doxorubicin $\left(\mathrm{IC}_{50}: 69.33 \mu \mathrm{m}\right)$ against $\mathrm{A} 549$ cells, demonstrating their potential to fight against lung cancer (Chinthala et al., 2015).

The antiproliferative SAR of 1,2,3-triazole-tethered chalconematrine hybrids 12a-c ( $\mathrm{IC}_{50}: 5.01-12.72 \mu \mathrm{m}$, MTT assay) against A549 cells reveals that the electron-withdrawing group at the $\mathrm{R}$ position could boost up the activity, and the representative compound 12a $\left(\mathrm{IC}_{50}: 5.01-7.31 \mu \mathrm{m}\right)$ not only exhibits the highest activity against the four tested cancer cell lines but also displays low cytotoxicity $\left(\mathrm{IC}_{50}: 39.21 \mu \mathrm{m}\right)$ toward normal NIH/3T3 cells (Zhao et al., 2015). A mechanistic study reveals that compound 12a could induce the apoptosis of A549 cells concentration-dependently in the A549-xenografted nude mouse model, and it also (10 mg/kg, tail vein injection) shows $85.4 \%$ tumor growth inhibition (TGI) after treatment for 16 days without causing obvious toxicities. Accordingly, compound 
<smiles>[R]n1cc(/C=C/C(=O)c2ccc(NC(=O)C3CCCC3)cc2)nn1</smiles>

7a: $\mathrm{R}=4-\mathrm{BrBn} ; \mathbf{7 b}: \mathrm{R}=\mathrm{n}-\mathrm{C}_{8} \mathrm{H}_{17}$; 7c: $\mathrm{R}=\mathrm{n}-\mathrm{C}_{11} \mathrm{H}_{25}$.<smiles>[R]c1cccc(-n2cc(COc3ccc(/C=C/C(=O)c4ccc(OC)cc4)c(OCC)c3)nn2)c1</smiles>

10

10a: $R=4-F ; 10 b: R=4-C l$.<smiles>[R]c1ccc(Cn2cc(COc3cccc(/C=C/C(=O)c4ccc(OC)cc4)c3)nn2)cc1</smiles>

8

8a: $R=3-F ; 8 b: R=4-B r$.<smiles>[R]c1ccc(Cn2cc(COc3cc(/C=C/C(=O)c4cc(OC)c(OC)c(OC)c4)ccc3OC)nn2)cc1</smiles>

9

9a: $\mathrm{R}=4-\mathrm{F} ; 9 \mathrm{~b}: \mathrm{R}=4-\mathrm{NH}_{2}$.<smiles>[R]c1cc2c(c([R])c1C(=O)/C=C/c1ccc(OCc3cn([R9])nn3)cc1)CCC(C)(C)O2</smiles>

11

11a: $\mathrm{R}_{1}=\mathrm{OH}, \mathrm{R}_{2}=\mathrm{H}, \mathrm{R}_{3}=4-\mathrm{NO}_{2} \mathrm{Bn}$ $11 b R_{1}=O H, R_{2}=H, R_{3}=n$-octane; 11c: $R_{1}=H, R_{2}=O H, R_{3}=$ n-pentane.

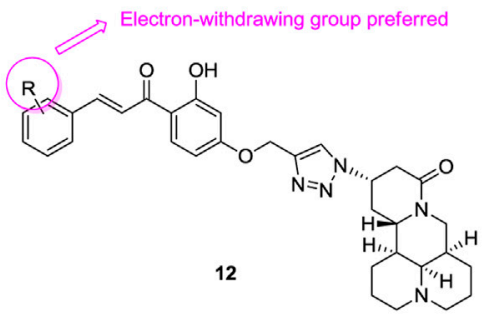

12a: $R=3-\mathrm{Cl} ;$ 12b: $R=3,4-$ diCl; 12c: $R=3-C_{3}$.

FIGURE 3 | Chemical structures of 1,2,3-triazole-containing chalcone derivatives 7-12.

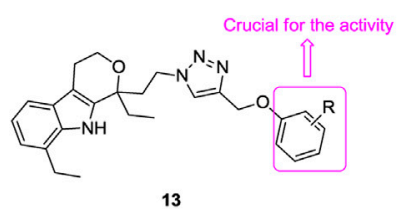

13

13a: $R=H ; 13 b: R=4-M e$

Substituent at $\mathrm{C}-5$ position preferred

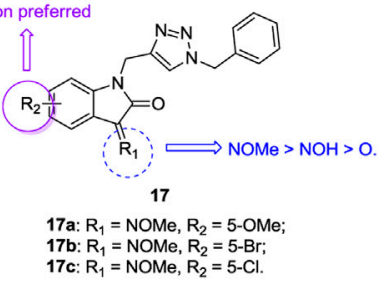

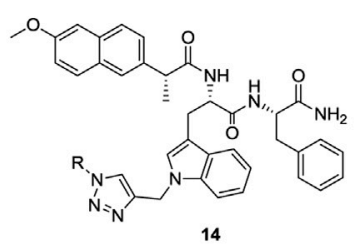

14a: $\mathrm{R}=2-\mathrm{CIPhCH}_{2} \mathrm{CO}$.

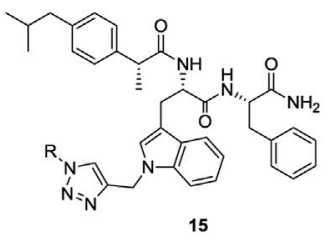

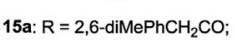
15b: $\mathrm{R}=2-\mathrm{NO}_{2} \mathrm{Ph}$.

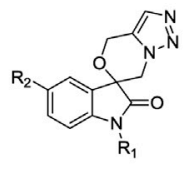

16

16a: $R_{1}=E t, R_{2}=H$;

16b: $R_{1}=4-B r B n, R_{2}=F$

16c: $R_{1}=4-B r B n, R_{2}=B$

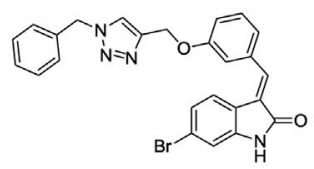

18a

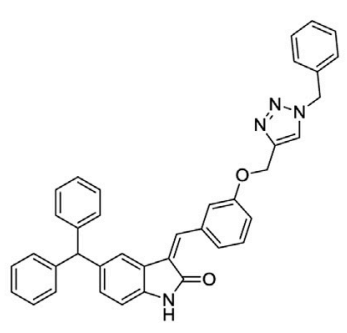

$18 b$

FIGURE 4 | Chemical structures of 1,2,3-triazole-containing indole derivatives 13-18.

12a could be considered as a promising candidate for the chemotherapy of lung cancer.

\section{1,2,3-TRIAZOLE-CONTAINING INDOLE DERIVATIVES}

Indoles, which could inhibit various enzymes and receptors, such as HDAC, proviral insertion site in moloney murine leukemia virus (Pim), and tubulin in cancer cells, are scaffolds to avail for developing novel anticancer agents (Guo and Diao, 2020; Xu and $\mathrm{Xu}, 2020$ ). Thus, combination of 1,2,3-triazole with indole represents a promising strategy to develop novel anticancer candidates that are effective against drug-sensitive and drugresistant cancers.

An antiproliferative SAR study of 1,2,3-triazole-containing etodolac derivatives 13 (Figure 4, $\mathrm{IC}_{50}$ : 3.29-10.71 $\mu \mathrm{m}$, MTT assay) against A549 cells revealed that the phenyl ring is crucial for the activity, and replacement by the naphthyl group results in loss of activity (Kummari et al., 2017). Introduction of substituents into the phenyl ring is generally detrimental to the activity, whereas methyl at the para position could enhance the activity slightly. The most active compounds 13a,b $\left(\mathrm{IC}_{50}\right.$ : 3.65 and $\left.3.29 \mu \mathrm{m}\right)$ display comparable activity to doxorubicin $\left(\mathrm{IC}_{50}: 3.30 \mu \mathrm{m}\right)$. Thus, these compounds can serve as promising lead candidates for further investigations. 1,2,3- 


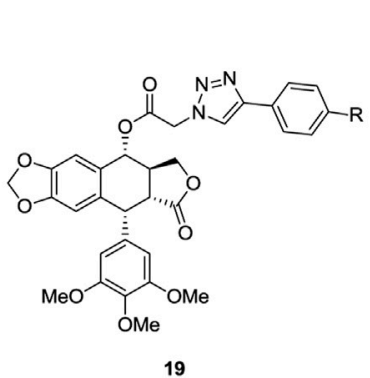

19

19a: $\mathrm{R}=4-\mathrm{NHBocBn}$ 19b: $\mathrm{R}=3-\mathrm{NO}_{2} \mathrm{Ph}$ : 19c: $R=4-C N P h$.



20a: $\mathrm{n}=0, \mathrm{R}=3,4$-dioxole 20b: $n=0, R=H$; 20c: $\mathrm{n}=0, \mathrm{R}=4-\mathrm{Cl}$; 20d: $\mathrm{n}=0, \mathrm{R}=4-\mathrm{OM}$ 20e: $n=0, R=4-C F_{3}$

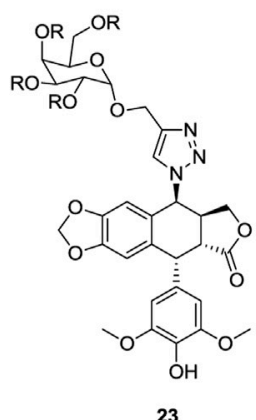

23a: $\mathrm{R}=\mathrm{H} ; \mathbf{2 3 b}: \mathrm{R}=\mathrm{COPr}$

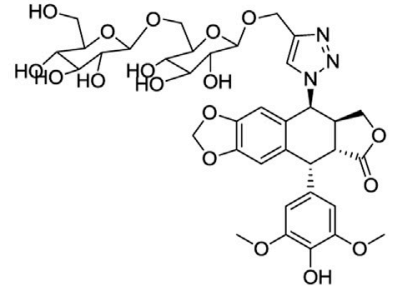

24

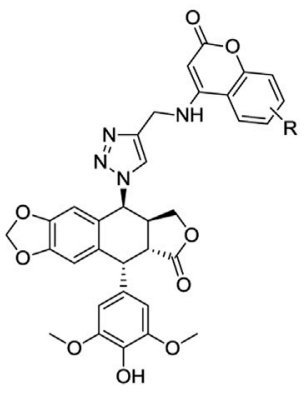

21

21a: $R=R=6-B r$ 21b: $R=6-O M e$.

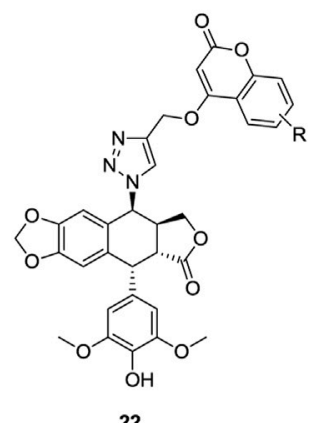

22

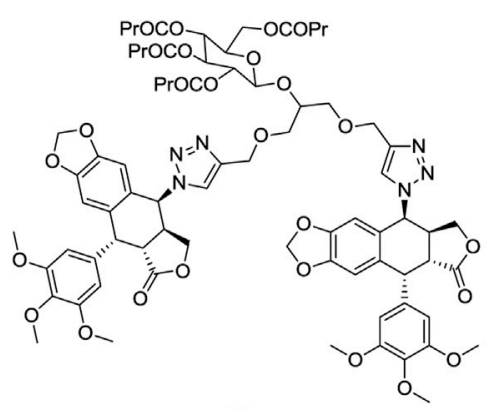

25

FIGURE 5 | Chemical structures of 1,2,3-triazole-containing (epi)podophyllotoxin derivatives 19-25.

Triazole-containing indole derivatives $14\left(\mathrm{IC}_{50}: 9.07-47.11 \mu \mathrm{m}\right.$, MTT assay) and 15 ( $\mathrm{IC}_{50}: 15.25-38.68 \mu \mathrm{m}$, MTT assay) show considerable activity against A549 cells, and the most potent compound 14a $\left(\mathrm{IC}_{50}: 9.07 \mu \mathrm{m}\right)$ is not inferior to doxorubicin $\left(\mathrm{IC}_{50}: 4.39 \mu \mathrm{m}\right)$ (Srinivas et al., 2020; Suryapeta et al., 2020).

The majority of spirooxindole-derived morpholine-fused 1,2,3-triazoles 16 ( $\mathrm{IC}_{50}$ : $1.87-23.44 \mu \mathrm{m}, \mathrm{MTT}$ assay) are active against A549 cells, and an SAR study implied that the para bromobenzyl group is more favorable than the alkyl group at the N-1 position of oxindole moiety (Senwar et al., 2015). In particular, the activity of compound $16 \mathrm{a}\left(\mathrm{IC}_{50}: 1.87 \mu \mathrm{m}\right)$ is comparable to that of doxorubicin $\left(\mathrm{IC}_{50}: 1.98 \mu \mathrm{m}\right.$ ) but 3.8 -fold superior to that of 5-fluorouracil ( $\left.\mathrm{IC}_{50}: 7.24 \mu \mathrm{m}\right)$. Further investigations demonstrated that compound 16a could arrest the A549 cells at the G2/M phase of the cell cycle and induce apoptosis in A549 cells through collapse of the mitochondrial membrane potential as well as elevation of intracellular ROS levels. Overall, compound 16a has the potential to act as a lead compound for the development of novel anticancer agents against lung adenocarcinoma A549 cancer cells.

An antiproliferative SAR study of 1,2,3-triazole-containing isatin compounds 17 ( $\mathrm{IC}_{50}: 0.99-27.33 \mu \mathrm{m}$, MTT assay) against NCI-H23 lung cancer cells disclosed that substituents at the C-3 and C-5 positions have great influence on the activity (Lan et al., 2020). Introduction of oxime to the $\mathrm{C}-3$ position could increase the activity, and the relative contribution order is methoxime $>$ oxime $>$ ketone. Electron-donating methoxy and halogen atoms at the C-5 position are preferred, whereas movement to the C-7 position causes great loss of activity. In particular, the most active compound $17 \mathbf{a}$ ( $\mathrm{IC}_{50}: 0.65 \mu \mathrm{m}$, MTT assay) is around 2 and 13 times superior to doxorubicin $\left(\mathrm{IC}_{50}: 1.12 \mu \mathrm{m}\right)$ and 5fluorouracil $\left(\mathrm{IC}_{50}: 8.84 \mu \mathrm{m}\right)$, respectively. Some other 1,2,3triazole-containing isatin compounds also hold certain activity against $\mathrm{A} 549$ cells, and the representative compounds 18a,b (IC I0 $_{14.7}$ and $9.6 \mu \mathrm{m}$, MTT assay) demonstrate the highest activity (Sharma et al., 2015; Nagarsenkar et al., 2016; Fan et al., 2018; Xu et al., 2018). Mechanistic studies indicate that hybrid 18a could induce cell apoptosis, cause cell cycle arrest at the G2/M phase, and lead to collapse of the mitochondrial membrane potential (Nagarsenkar et al., 2016).

\section{1,2,3-TRIAZOLE-CONTAINING PODOPHYLLOTOXIN/ EPIPODOPHYLLOTOXIN DERIVATIVES}

Podophyllotoxins show antiproliferative activity by inhibiting tubulin polymerization, and epipodophyllotoxins are inhibitors of topoisomerase II (Sathish et al., 2018; Xiao et al., 2020). Some podophyllotoxin-/epipodophyllotoxin-based agents, such as 


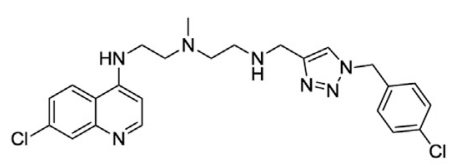

26 (EAD1)

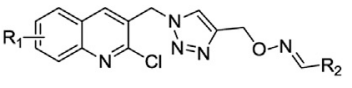

29

29a: $R_{1}=7-M e, R_{2}=2$-chloroquinolin-3-yl.
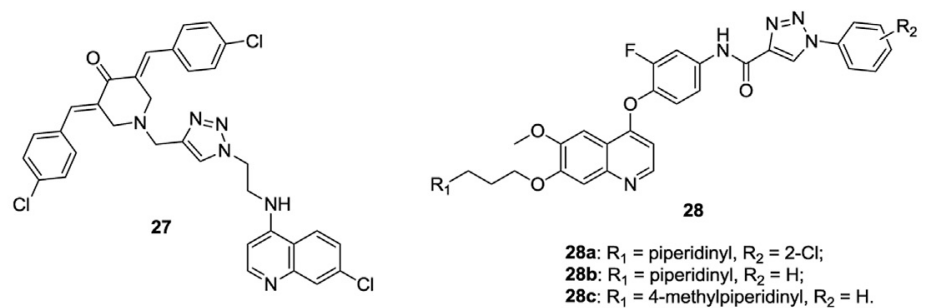


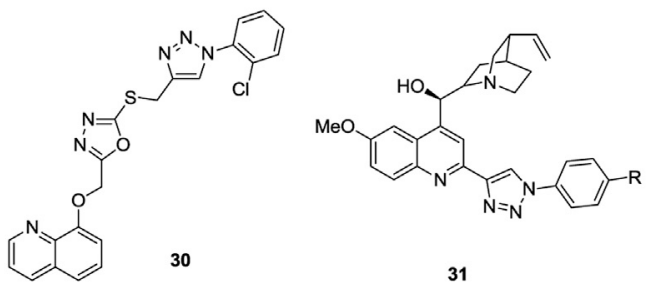

31

31a: $R=H ; 31 b: R=O H$

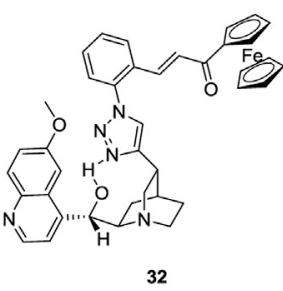

32

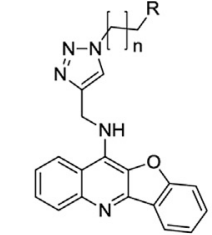

33

33a: $n=1, R=N$-methylpiperazinyl; 33b: $n=2, R=$ pyrrolidiny

FIGURE 6 | Chemical structures of 1,2,3-triazole-containing quinoline/quinolone derivatives 26-34.

etoposide and teniposide, have already been approved for cancer therapy, revealing that podophyllotoxin/epipodophyllotoxin derivatives are promising as novel anticancer agents (Kamal et al., 2015; Routh and Nandagopal, 2017).

1,2,3-Triazole-containing podophyllotoxin derivatives 19 (Figure 5, $\mathrm{IC}_{50}$ : 21.1-118.8 nM, MTT assay) are highly potent against A549 cells, and compounds 19a-c ( $\mathrm{IC}_{50}$ : 21.1-29.4 nM) are comparable to podophyllotoxin ( $\mathrm{IC}_{50}: 27.1 \mathrm{nM}$ ) (Hou et al., 2019). Mechanistic investigations show that hybrid 19a could exert antiproliferative activity through acting on microtubules, causing cell cycle arrest at the $\mathrm{G} 2 / \mathrm{M}$ phase, and inducing apoptosis cancer cells.

1,2,3-Triazole-containing epipodophyllotoxin derivatives 20 ( IC $_{50}: 0.97-34.46 \mu \mathrm{m}, \mathrm{MTT}$ assay) exhibit considerable activity against A549 cells, and an SAR study implies that introduction of a carbon spacer between 1,2,3-triazole and phenyl ring reduces the activity (Reddy et al., 2018). Compounds 20a-e ( $\mathrm{IC}_{50}$ : $0.97-1.96 \mu \mathrm{m})$ possess higher activity than the references podophyllotoxin $\left(\mathrm{IC}_{50}: 4.60 \mu \mathrm{m}\right)$ and etoposide $\left(\mathrm{IC}_{50}: 1.97 \mu \mathrm{m}\right)$, and the cytotoxicity $\left(\mathrm{IC}_{50}: 53.86-89.04 \mu \mathrm{m}\right)$ toward $\mathrm{NIH} / 3 \mathrm{~T} 3$ cells is much lower. A mechanistic study demonstrates that these hybrids could inhibit topoisomerase II, arrest G2/M phase of cell cycle, and induce apoptosis.

1,2,3-Triazole-tethered podophyllotoxin-coumarin hybrids 21 ( $\mathrm{IC}_{50}$ : 8.6-34.8 $\mu \mathrm{m}$, MTT assay) show higher antiproliferative activity than their analogues 22 ( $\mathrm{IC}_{50}$ : 19.6-
$>100 \mu \mathrm{m})$ against A549 cells, revealing that the amino linker to couple 1,2,3-triazole with coumarin moieties is more favorable than ether linker (Hao et al., 2019). In addition, substituents into the C-6 position of the coumarin moiety and the electronwithdrawing group are beneficial for the activity. In particular, hybrids 21a,b $\left(\mathrm{IC}_{50}: 8.6\right.$ and $\left.17.5 \mu \mathrm{m}\right)$ are found much more potent than the reference etoposide $\left(\mathrm{IC}_{50}: 25.6 \mu \mathrm{m}\right)$ against $\mathrm{A} 549$ cells, and hybrid $21 \mathbf{b}$ could disrupt microtubules and induce cell cycle arrest at the G1 phase by regulating P21 and cyclin D1.

1,2,3-Triazole-tethered epipodophyllotoxin-galactose hybrid 23a possesses potent broad-spectrum antiproliferative activity, and the activity against $\mathrm{A} 549$ cells ( $\mathrm{IC}_{50}: 4.07 \mu \mathrm{m}, \mathrm{MTT}$ assay) is 2 -fold higher than that of cisplatin ( $\mathrm{IC}_{50}: 9.24 \mu \mathrm{m}$ ) and etoposide $\left(\mathrm{IC}_{50}: 11.92 \mu \mathrm{m}\right)$ (Zi et al., 2015). An SAR study reveals that butyrylation of the galactose moiety generally benefits for the activity, as evidenced by that hybrid $\mathbf{2 3 b}\left(\mathrm{IC}_{50}: 1.52 \mu \mathrm{m}\right)$ is six times superior to cisplatin $\left(\mathrm{IC}_{50}: 9.24 \mu \mathrm{m}\right)$ and etoposide $\left(\mathrm{IC}_{50}\right.$ : $11.92 \mu \mathrm{m}$ ) against A549 cells (Zi et al., 2015).

The majority of 1,2,3-triazole-tethered epipodophyllotoxinbis-glucose hybrids $\left(\mathrm{IC}_{50}\right.$ : $>40 \mu \mathrm{m}, \mathrm{MTT}$ assay) are devoid of activity against $\mathrm{A} 549$ cells, but hybrid $24\left(\mathrm{IC}_{50}: 3.84 \mu \mathrm{m}\right)$ demonstrates higher activity than the references cisplatin $\left(\mathrm{IC}_{50}: 6.15 \mu \mathrm{m}\right)$ and etoposide $\left(\mathrm{IC}_{50}: 11.92 \mu \mathrm{m}\right)$ (Zi et al., 2017). Similar results are also observed for bis-1,2,3triazole-tethered bis-epipodophyllotoxin-glucose hybrids $\left(\mathrm{IC}_{50}\right.$ : $>40 \mu \mathrm{m}$, MTT assay). Only hybrid $25\left(\mathrm{IC}_{50}: 0.89 \mu \mathrm{m}\right)$ displays 
excellent inhibitory activity against A549 cells, and the activity is 6.9- and 13.3-folds superior to those of cisplatin ( $\mathrm{IC}_{50}: 6.15 \mu \mathrm{m}$ ) and etoposide ( $\mathrm{IC}_{50}: 11.92 \mu \mathrm{m}$ ) (Zi et al., 2018). This hybrid $\left(\mathrm{CC}_{50}: 15.38 \mu \mathrm{m}\right)$ also shows relatively low cytotoxicity against normal BEAS-2B cells, and the SI is 17.2. Accordingly, hybrid 25 could serve as a lead compound for further investigations.

\section{1,2,3-TRIAZOLE-CONTAINING QUINOLINE/QUINOLONE DERIVATIVES}

Quinoline and quinolone derivatives are potential inhibitors of hepatocyte growth factor receptor, proto-oncogene receptor tyrosine kinase/KIT, platelet-derived growth factor receptor$\beta /$ PDGFR- $\beta$ and VEGFR2, and some quinoline-/quinolonebased agents, such as anlotinib and lenvatinib, have already been approved for lung cancer therapy (Jain et al., 2019; Li and Zhu, 2021). Hence, combination of 1,2,3-triazole with quinoline/quinolone may provide valuable therapeutic drug candidates against lung cancer.

The majority of 1,2,3-triazole-containing quinoline derivatives $\left(\mathrm{IC}_{50}\right.$ : $7.6-164 \mu \mathrm{m}$, SAR assay) are active against H460 and HCC827 human lung cancer cell lines, and compound 26 (EAD1, Figure 6, $\mathrm{IC}_{50}: 11$ and $7.6 \mu \mathrm{m}$ ) is more potent than chloroquinoline $\left(\mathrm{IC}_{50}: 52\right.$ and $76 \mu \mathrm{m}$ ) (Nordstrøm et al., 2015). A mechanistic study indicates that compound $\mathbf{2 6}$ exerts antiproliferative activity by inhibiting autophagy and inducing apoptosis. Compound $27\left(\mathrm{GI}_{50}: 0.189-2.17 \mu \mathrm{m}, \mathrm{SRB}\right.$ assay) demonstrates promising activity against a series of cancer cell lines, including eight NSCLC $\left(\mathrm{GI}_{50}: 0.25-1.91 \mu \mathrm{m}\right)$, and a mechanistic study reveals that this hybrid could induce apoptosis (Kandi et al., 2015). Compounds 28 ( IC $_{50}: 0.07-3.50 \mu \mathrm{m}, \mathrm{MTT}$ assay) display potential activity against A549 cells, and an SAR study elucidates that the piperidinyl group at the $R_{1}$ position enhances the activity (Liu et al., 2016). Among them, compounds 28a-c $\left(\mathrm{IC}_{50}: 0.07-0.14 \mu \mathrm{m}\right)$ are not inferior to foretinib $\left(\mathrm{IC}_{50}\right.$ : $0.11 \mu \mathrm{m}$ ). In particular, the most active compound 28a with an $\mathrm{IC}_{50}$ value of $2.27 \mathrm{nM}$ against c-Met is identified as a multitargeted receptor tyrosine kinase inhibitor. Thus, this compound is worthy of further investigation. Some 1,2,3triazole-containing 2-chloroquinoline derivatives, such as compound 29 ( $\mathrm{IC}_{50}: 9.8 \mu \mathrm{m}$ against $\mathrm{A} 549$ cells, MTT assay; $9.7 \mu \mathrm{m}$ for doxorubicin), also display certain antiproliferative activity against lung cancer cells, but most of them are less potent than the references (Praveena et al., 2016; Dasari et al., 2019). Further modifications implies that incorporation of azole between 1,2,3-triazole and quinoline moieties is also allowed, and 1,2,3-triazole-tethered 1,3,4-oxadiazole-quinoline compound 30 $\left(\mathrm{IC}_{50}: 5.6 \mu \mathrm{m}, \mathrm{MTT}\right.$ assay) is comparable to doxorubicin $\left(\mathrm{IC}_{50}\right.$ : $1.83 \mu \mathrm{m}$ ) against A549 cells (Rachakonda et al., 2017; Shamsi et al., 2019).

The antiproliferative activity of 1,2,3-triazole-containing quinine derivatives $\mathbf{3 1 a}, \mathbf{b}$ ( $\mathrm{IC}_{50}: 3.3$ and $4.7 \mu \mathrm{m}$, MTT assay) is comparable to that of cisplatin $\left(\mathrm{IC}_{50}: 3.5 \mu \mathrm{m}\right)$ against $\mathrm{A} 549$ cells (Boratynski et al., 2018), while compound 32 ( $\mathrm{IC}_{50}: 2.34$ and $2.13 \mu \mathrm{m}$, MTT assay) shows promising activity against drugsensitive NCI-H460 and MDR NCI-H460/R; probably due to that this compound could increase ROS production and induce mitochondrial damage in MDR cancer cells, demonstrating its potential against MDR lung carcinoma (Podolski-Renic et al., 2017).

Aside from the 1,2,3-triazole-containing quinoline derivatives mentioned above, some other derivtives are also endowed with certain activity against lung cancer cells (Theeramunkong et al., 2016; Zeng et al., 2017; Qiao et al., 2019; Rono et al., 2019). 1,2,3Triazole-containing benzofuroquinoline derivatives 33a,b $\left(\mathrm{IC}_{50}\right.$ : 0.53 and $0.26 \mu \mathrm{m}$, MTT assay) exhibit excellent activity against A549 cells and low cytotoxicity ( $\mathrm{IC}_{50}: 25.24$ and $\left.16.05 \mu \mathrm{m}\right)$ toward mouse mesangial cells (Zeng et al., 2017). A mechanistic study reveals that compound $\mathbf{3 3 b}$ could exert antiproliferative activity by inducing G0/G1 phase arrest and down-regulating $c$-myc gene transcription.

1,2,3-Triazole-tethered ciprofloxacin/gatifloxacin/ moxifloxacin-isatin hybrids are also active against A549 cells, and hybrid 34 ( $\mathrm{IC}_{50}: 44.2 \mu \mathrm{m}, \mathrm{CCK}-8$ assay) is more potent than vorinostat $\left(\mathrm{IC}_{50}: 76.3 \mu \mathrm{m}\right)$, revealing that these types of hybrids could be taken for further investigations (Chen et al., 2019; Jiang and Zhang, 2019; Yang et al., 2020).

\section{1,2,3-TRIAZOLE-CONTAINING PYRIDINE DERIVATIVES}

Pyridines are potential inhibitors of CDK, EGFR, PI3K, and RGGT, and some pyridine-based agents, such as masitinib, have already been applied in clinical practice or under clinical trials for the treatment of cancers (Goel et al., 2016; Prachayasittikul et al., 2017). Thus, combination of 1,2,3triazole with pyridine may provide opportunities for the development of novel anticancer agents.

An antiproliferative SAR of 1,2,3-triazole-containing pyridine derivatives 35 (Figure 7, $\mathrm{IC}_{50}: 1.023-23.61 \mu \mathrm{m}, \mathrm{MTT}$ assay) against A549 cells indicates that the methoxy group on the 2-arylpyridine moiety ( $\mathrm{R}_{1}$ position) and the 3-phenoxy group on the benzyl group are favorable for the activity (Kamal et al., 2015; Prasad et al., 2019). The most active compounds 35a-c ( $\left.\mathrm{IC}_{50}: 1.023-1.148 \mu \mathrm{m}\right)$ exhibit higher activity than the reference $\mathrm{E} 7010\left(\mathrm{IC}_{50}: 1.622 \mu \mathrm{m}\right)$, and mechanistic studies reveals that these compounds could inhibit the microtubule assembly, arrest the cell cycle at the G2/M phase, and induce cell death by apoptosis. BD7 (36, IC S0 $_{50}$ 0.07-0.49 $\mu \mathrm{m}, \mathrm{MTT}$ assay) shows potent antiproliferative activity against various cancer cell lines, and its activity is identical to that of sorafenib $\left(\mathrm{IC}_{50}\right.$ : $0.08-0.30 \mu \mathrm{m}$ ) (Pan et al., 2019). Biological results indicate that BD7 displays simultaneous inhibition of VEGFR-2, Tie-2, and EphB4. Thus, this compound could be considered as a promising template for further optimization of 1,2,3-trizole-incorporated derivatives as VEGFR-2/Tie-2/EphB4 inhibitors. BTCP (37a, $\mathrm{IC}_{50}: 42.6 \mu \mathrm{m}, \mathrm{MTT}$ assay) is not inferior to doxorubicin ( $\mathrm{IC}_{50}$ : $38.2 \mu \mathrm{m})$ against A549 cells, and BTPT (37b, IC S0: $_{0.68 \mu \mathrm{m}, \mathrm{MTT}}$ assay) with the thiophene moiety at the para position of the pyridine moiety holds enhanced activity against A549 cells (Murugavel et al., 2019; Murugavel et al., 2019).

An antiproliferative SAR study of 1,2,3-triazole-containing pyridine derivatives $\mathbf{3 8}$ against A549 cells demonstrates that the 


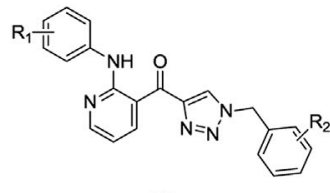

35

35a: $R_{1}=3,5-d i O M e, R_{2}=3-O P h ;$ 35b: $R_{1}=4-\mathrm{OMe}, R_{2}=4-\mathrm{OMe}$ 35c: $R_{1}=3,4$-diOMe, $R_{2}=3-O P h$



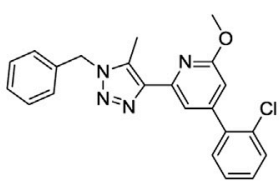

37a (BTCP)

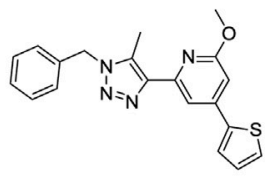

37b (BTPT)


40a: $R_{1}=F, R_{2}=C F_{3}, R_{3}=4-F$; 40b: $R_{1}=F, R_{2}=C_{3}, R_{3}=2-F$; 40c: $R_{1}=H, R_{2}=C_{3}, R_{3}=4-F$; 40d: $R_{1}=F, R_{2}=C_{3}, R_{3}=4-F$.
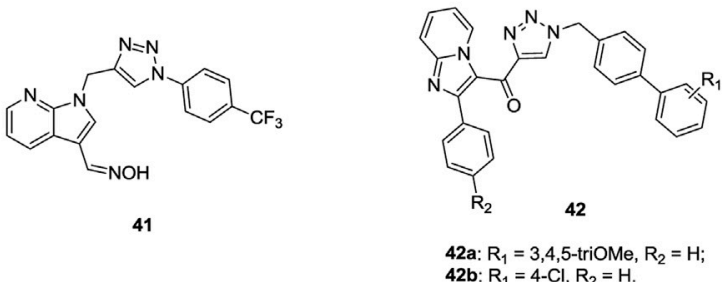

FIGURE 7 | Chemical structures of 1,2,3-triazole-containing pyridine derivatives 35-42.

methyl group on the 1,2,3-triazole motif and the fluoro on the phenyl ring are advantageous to the activity (Xiong et al., 2020). The morpholino group is essential for high activity, while replacement by pyrrolidinyl, thienyl, and alkyl groups leads to great loss of activity. In particular, compounds 38a-c $\left(\mathrm{IC}_{50}\right.$ : $3.22-6.43 \mu \mathrm{m}$, MTT assay) are more potent than golvatoinib $\left(\mathrm{IC}_{50}: 8.14 \mu \mathrm{m}\right)$, and the most active compound $\mathbf{3 8 b}$ could block cells in the G0/G1 phase. 1,2,3-Triazole-containing isoxazole-thiazole-pyridine hybrids 39 ( $\mathrm{IC}_{50}$ : $0.01-10.22 \mu \mathrm{m}$, MTT assay) has promising activity against A549 cells, and an SAR study implies that electron-withdrawing groups, especially the nitro group on the phenyl ring, could greatly increase the activity (Yakantham et al., 2019). The most active hybrid 39b $\left(\mathrm{IC}_{50}: 0.01 \mu \mathrm{m}\right)$ is 308 -fold more potent than etoposide $\left(\mathrm{IC}_{50}\right.$ : $3.08 \mu \mathrm{m}$ ) against A549 cells, so it could serve as a lead compound for further development of novel anti-lung cancer candidates.

1,2,3-Triazole-containing pyrrolo(2,3-b)pyridines 40 ( $\mathrm{IC}_{50}$ : $0.082-2.83 \mu \mathrm{m}$, MTT assay) exhibit excellent activity against A549 cells, and an SAR study demonstrates that the fluoro at the $R_{1}$ position and the trifluoromethyl group at the $R_{2}$ position are beneficial for the activity (Tang et al., 2016; Wang et al., 2018). The activity of representative compounds 40a-d $\left(\mathrm{IC}_{50}\right.$ : $0.082-0.19 \mu \mathrm{m}$, MTT assay) is higher than that of foretinib $\left(\mathrm{IC}_{50}: 0.49 \mu \mathrm{m}\right)$, and compound $40 \mathrm{a} \quad\left(\mathrm{IC}_{50}: 1.68-4.57 \mathrm{nM}\right)$ shows excellent inhibitory activity against c-Met, Flt-3, and PDGFR- $\beta$. Further study disclosed that incorporation of oxime into the pyrrolo(2,3-b)pyridine moiety $\left(\mathrm{IC}_{50}: 0.12-3.84 \mu \mathrm{m}, \mathrm{MTT}\right.$ assay) is permitted, and the most active compound $41\left(\mathrm{IC}_{50}\right.$ : $0.12 \mu \mathrm{m}$ ) could intercalate into calf thymus DNA efficiently to form a 41-DNA complex that might block DNA replication to exert its antiproliferative activity (Narva et al., 2016).

1,2,3-Triazole-containing imidazopyridines $42 \quad\left(\mathrm{IC}_{50}\right.$ : $0.51-47.92 \mu \mathrm{m}$, MTT assay) show considerable activity against A549 cells, and an SAR study illustrated that a substitution at the $\mathrm{R}_{2}$ position, regardless if the substituent is an electron-donating or electron-withdrawing group, could reduce the activity as compared with hydrogen (Sayeed et al., 2018). In particular, compounds $42 \mathbf{a}, \mathbf{b}\left(\mathrm{IC}_{50}: 0.51\right.$ and $\left.0.63 \mu \mathrm{m}\right)$ are more potent than nocodazole $\left(\mathrm{IC}_{50}: 1.47 \mu \mathrm{m}\right)$ against $\mathrm{A} 549$ cells. Flow cytometry reveals that these compounds result in A549 cell cycle arrest at the G2/M phase, and further studies indicates that these compounds could inhibit tubulin and induce cell death by apoptosis.

\section{1,2,3-TRIAZOLE-CONTAINING PYRIMIDINE/QUINAZOLINONE/ NUCLEOSIDE DERIVATIVES}

Pyrimidines, quinazolinones, and nucleosides could inhibit various MDR proteins, such as $\mathrm{P}$-gp and MDR-associated protein-1, and several pyrimidine-/quinazolinone-/nucleosidebased agents, such as azacitidine and gemcitabine, demonstrate 


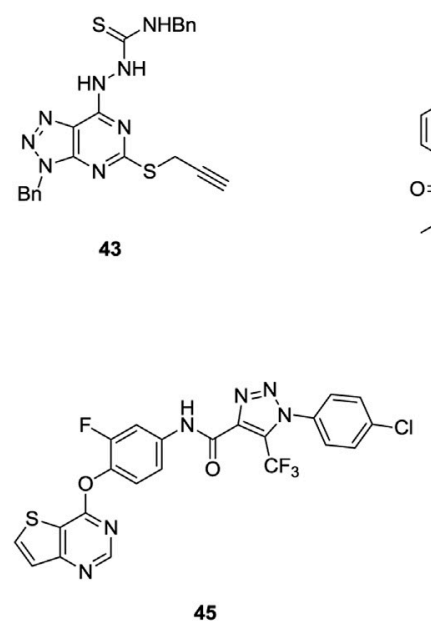

45<smiles>CCOC(=O)C1=C(Cn2cc(COc3ccccc3C3NC(=O)NC(CCl)=C3C(=O)OCC)nn2)C(=O)NC(=O)NC1c1ccccc1Cl</smiles><smiles>[R3]c1nc2nc(C)ccc2c(=O)n1Cc1cn([R])nn1</smiles>

51

51a: $\mathrm{R}_{1}=\mathrm{Et}, \mathrm{R}_{2}=\mathrm{n}-\mathrm{CH}_{2} \mathrm{CH}_{2} \mathrm{C}_{6} \mathrm{~F}_{13}$; 51b: $\mathrm{R}_{1}=\mathrm{C}_{4} \mathrm{H}_{3} \mathrm{O}, \mathrm{R}_{2}=\mathrm{n}-\mathrm{C}_{10} \mathrm{H}_{21}$; 51c: $R_{1}=H, R_{2}=4-\mathrm{NO}_{2} \mathrm{Ph}$.<smiles>COc1cc(-n2cc(CN3CCCC3CO)nn2)ccc1Nc1ncc(Cl)c(Nc2ccccc2S(=O)(=O)C(C)C)n1</smiles><smiles>Nc1nc(N2CCCC2)nc2c1ncn2Cc1cn(-c2c[R]ccc2)nn1</smiles>

46

46a: $\mathrm{n}=1, \mathrm{R}=2-\mathrm{F}$; 46b: $n=1, R=2-C$ 46c: $n=2, R=H$.

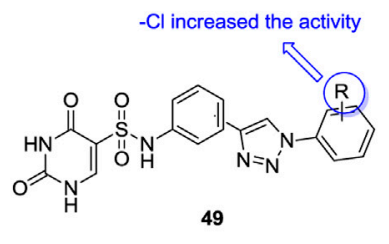

49a: ortho-position, $\mathrm{R}=2$-Cl; 49b: meta-position, $\mathrm{R}=2$-Cl; 49c: para-position, $\mathrm{R}=2-\mathrm{Cl}$; 49d: ortho-position, $\mathrm{R}=3-\mathrm{Cl}$ 49e: meta-position, $\mathrm{R}=3-\mathrm{Cl}$ 49f: paraposition, $\mathrm{R}=3 \mathrm{Cl}$ 49: parapostion, $\mathrm{R}=3-\mathrm{Cl}$; 49g. ortho-position, $\mathrm{R}=4-\mathrm{Cl}$ 49h: meta-position, $\mathrm{R}=4-\mathrm{Cl}$;<smiles>CCCCOc1ccc(C2NC(=O)NC(C)=C2n2cc(-c3ccccc3)nn2)cc1</smiles>

$47 a$<smiles>O=C1NC(Cn2cc(C3CC3)nn2)=C(n2cc(-c3ccccc3)nn2)C(c2ccc(Cl)cc2)N1</smiles><smiles>CCOC(=O)C1=C(C)Oc2nc(C)n(Cc3cn(-c4ccc([N+](=O)[O-])cc4)nn3)c(=O)c2C1c1ccccc1</smiles>

50<smiles>CN1C(=O)C2C(N=CN2CC(=O)OCc2cn(CCC(=O)Nc3ccc(-c4ccccc4)nn3)nn2)N(C)C1=O</smiles>

53

FIGURE 8 | Chemical structures of 1,2,3-triazole-containing pyrimidine derivatives 43-53.

high efficacy for a broad spectrum of cancers (Robak, 2011; Patil, 2018; He et al., 2020). Therefore, 1,2,3-triazole-containing pyrimidine/quinazolinone/nucleoside derivatives may have the potency to overcome MDR, and they may represent promising leads for the development of novel anticancer agents.

1,2,3-Triazolo(4,5-d)pyrimidine 43 (Figure 8, $\mathrm{IC}_{50}: 2.37 \mu \mathrm{m}$, MTT assay) is 3.3 folds more potent than 5 -flurouracil $\left(\mathrm{IC}_{50}\right.$ : $7.86 \mu \mathrm{m})$ against NCI-H1650 cells, and mechanistic studies disclose that this compound can inhibit the migration of cancer cells and induce apoptosis (Geng et al., 2018). 1,2,3Triazole-containing pyrimidine derivatives 44a,b ( $\mathrm{IC}_{50}$ : $0.29-0.91 \mu \mathrm{m}$, MTT assay) hold potential activity against A549 and the NSCLC cell line H2228 expressing EML4-ALK, and both of them display superior activity to crizotinib $\left(\mathrm{IC}_{50}:>1 \mu \mathrm{m}\right)$ and ceritinib ( $\mathrm{IC}_{50}:>1 \mu \mathrm{m}$ ) against A549 cells (Wang et al., 2018). Further study indicates that these compounds could induce cell apoptosis and inhibit cellular ALK and ROS1 activities. Accordingly, these compounds could act as promising ALK and ROS1 dual inhibitors to overcome crizotinib-resistant mutants. 1,2,3-Triazole-pyrrolopyrimidine/imidazo(2,3-d) pyrimidine/thieno(3,2-d)pyrimidines also possess certain activity against lung cancer cell lines, and among them, compound 45 ( $\mathrm{IC}_{50}: 0.9 \mu \mathrm{m}$, MTT assay) is 5.2 times more potent than foretinib $\left(\mathrm{IC}_{50}: 4.7 \mu \mathrm{m}\right.$ ) against A549 cells (Lee et al., 2016; Bistrovic et al., 2018; Wang et al., 2018). A mechanistic investigation reveals that compound 45 could 




54a: $\mathrm{R}_{1}, \mathrm{R}_{2}=-\mathrm{O}\left(\mathrm{CH}_{2}\right)_{2} \mathrm{O}-, \mathrm{R}_{3}=2-\mathrm{NO}_{2}$; 54b: $\mathrm{R}_{1}, \mathrm{R}_{2}=-\mathrm{O}\left(\mathrm{CH}_{2}\right)_{3} \mathrm{O}-, \mathrm{R}_{3}=3-\mathrm{CN}-4-\mathrm{NO}_{2}$

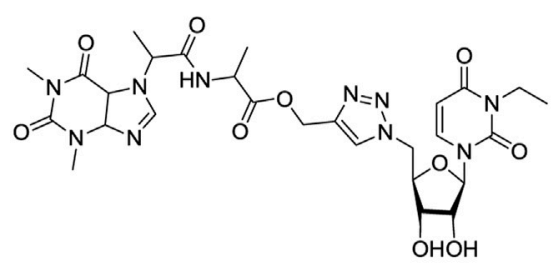

$57 a$

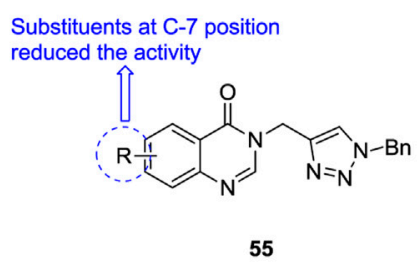

55a: $\mathrm{R}=\mathrm{H} ; \mathbf{5 5 b}: \mathrm{R}=6-\mathrm{Br}$; 55c: $R=6-M e$
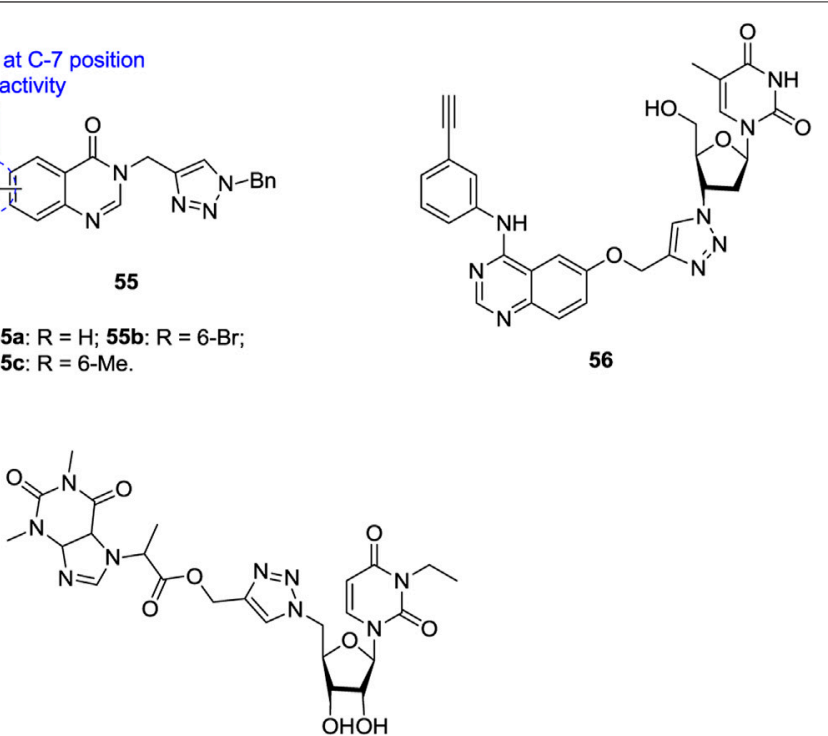

$57 b$

FIGURE 9 | Chemical structures of 1,2,3-triazole-containing quinazoline/nucleoside derivatives 54-57.

induce apoptosis in a concentration-dependent manner (Wang et al., 2018). The majority of 1,2,3-triazole-containing purine derivatives 46 ( $\mathrm{IC}_{50}$ : 0.03-45.2 $\mu \mathrm{m}$, SRB assay) display inhibitory activity against $\mathrm{A} 549$ cells, and three compounds 46a-c $\left(\mathrm{IC}_{50}\right.$ : $0.03-0.14 \mu \mathrm{m})$ are 35-163.3 folds more potent than 5-fluorouracil $\left(\mathrm{IC}_{50}: 4.9 \mu \mathrm{m}\right)$, revealing the potential of these compounds as novel anti-lung cancer agents (Khazir et al., 2020).

1,2,3-Triazole-containing dihydropyrimidinone $47 \mathbf{a}\left(\mathrm{GI}_{50}: 14\right.$ and $18 \mu \mathrm{m}, \mathrm{SRB}$ assay) and its derivative $47 \mathrm{~b}\left(\mathrm{GI}_{50}: 15\right.$ and $17 \mu \mathrm{m})$ show considerable activity against SW1573 and A549 lung cancer cell lines (Caeeeiro et al., 2020), but incorporation of the second dihydropyrimidinone fragment does not positively affect the activity; as evidenced by that compound $48\left(\mathrm{IC}_{50}\right.$ : $20 \mu \mathrm{m}$, MTT assay) shows moderate activity against A549 cells (Shamsiya and Damodaran, 2019). 1,2,3-Triazole-containing dihydropyrimidinones 49a-i ( $\mathrm{IC}_{50}$ : $1.18-2.81 \mu \mathrm{m}$, MTT assay) are more potent than pemetrexed $\left(\mathrm{IC}_{50}: 3.29 \mu \mathrm{m}\right)$ against $\mathrm{A} 549$ cells, and an SAR study illustrates that the chloro on the phenyl rings enhance the activity (Lu et al., 2019). Flow cytometric analysis shows that compound $49 \mathrm{~g}$ could inhibit the proliferation of A549 cells by arresting the cell cycle in the G1/S phase and inducing cell apoptosis. The 1,2,3triazole-containing $3 \mathrm{H}$-pyrano(2,3-d)pyrimidinone-6carboxylate 50 ( $\mathrm{IC}_{50}: 0.69 \mu \mathrm{m}, \mathrm{MTT}$ assay) shows slightly lower potency than the reference doxorubicin $\left(\mathrm{IC}_{50}: 0.14 \mu \mathrm{m}\right)$ against A549 cells, demonstrating its potential as a lead compound for further development of new therapeutic drug candidates (Boda et al., 2018). 1,2,3-Triazole-containing pyrido(2,3-d)pyrimidinones $\mathbf{5 1} \quad\left(\mathrm{GI}_{50}: \quad 0.03-5.33 \mu \mathrm{m}, \quad \mathrm{SRB}\right.$ assay) are active against A549 cells, and the most active compound 51a $\left(\mathrm{GI}_{50}: 0.03 \mu \mathrm{m}\right)$ is more potent than the reference nocodazole $\left(\mathrm{GI}_{50}: 0.08 \mu \mathrm{m}\right)$ (Kumar et al., 2016). Similar activity of compounds 52a,b ( IC $_{50}: 3.06$ and $4.69 \mu \mathrm{m}$,
MTT assay) to 5-fluorouracil ( $\left.\mathrm{IC}_{50}: 2.80 \mu \mathrm{m}\right)$ is also observed, but both the compounds 52a,b ( $\mathrm{IC}_{50}: 2.22$ and $\left.0.04 \mu \mathrm{m}\right)$ display high cytotoxicity toward normal NIH 3T3 cells (Gregoric et al., 2017). Compound 53 ( IC $_{50}: 1.34 \mu \mathrm{m}, \mathrm{MTT}$ assay) also exhibits considerable activity against A549 cells, but it is less potent than combretastatin-A4 $\left(\mathrm{IC}_{50}: 0.11 \mu \mathrm{m}\right)$ (Ruddarraju et al., 2017).

Most of 1,2,3-triazole-containing quinazoline derivatives 54 (Figure 9, $\mathrm{IC}_{50}: 1.03-9.16 \mu \mathrm{m}, \mathrm{MTT}$ assay) possess potential activity against SK-Lu-1 NSCLC, and the activity is superior to that of erlotinib ( $\left.\mathrm{IC}_{50}: 99.76 \mu \mathrm{m}\right)$ (Le-Nhat-Thuy et al., 2018). An SAR study implies that the introduction of a nitro group into the ortho position of the phenyl ring at the N-1 position of the 1,2,3triazole moiety could boost the activity to some extent. The representative compounds 54a,b ( $\mathrm{IC}_{50}: 1.03$ and $1.81 \mu \mathrm{m}$ ) possess comparable activity to ellipticine $\left(\mathrm{IC}_{50}: 1.38 \mu \mathrm{m}\right)$, and molecular docking studies indicates that these compounds could exert antiproliferative activity through targeting EGFR.

Some 1,2,3-triazole-containing quinazolin-4(3H)-one derivatives also demonstrate considerable activity against lung cancer cell lines, and an antiproliferative SAR study of compounds 55 ( IC $_{50}$ : 2.01-12.34 $\mu \mathrm{m}$, MTT assay) against NCIH23 lung cancer cells elucidates that introduction of substituents into the quinazolin- $4(3 H)$-one motif, especially at the C-7 position, is unfavorable to the activity (Safavi et al., 2018; Vasu et al., 2018; Lan et al., 2020). No inferior activity is found for compounds 55a-c ( $\left.\mathrm{IC}_{50}: 2.01-2.69 \mu \mathrm{m}\right)$ compared with doxorubicin $\left(\mathrm{IC}_{50}: 1.29 \mu \mathrm{m}\right)$ and SAHA $\left(\mathrm{IC}_{50}: 1.44 \mu \mathrm{m}\right)$, and compounds 55a-c are around six folds more potent than 5fluorouracil $\left(\mathrm{IC}_{50}: 13.45 \mu \mathrm{m}\right)$. The most active compound 55a could induce early apoptosis and arrest at the G2/M phase. Thus, it could serve as a new lead for the design and development of potent anticancer agents. 




58c: $\mathrm{R}=3,4-\mathrm{OCH}_{2} \mathrm{O}$.

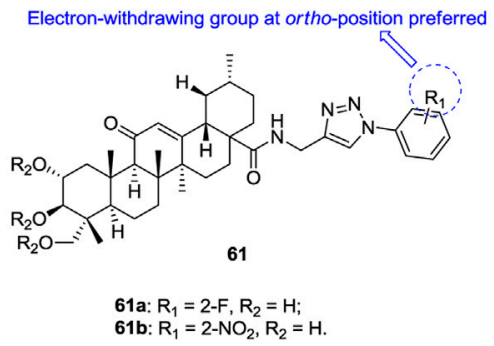

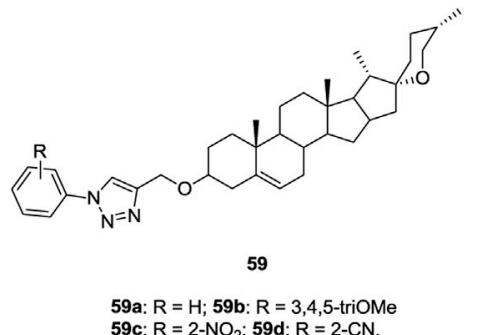

59c: $R=2-\mathrm{NO}_{2} ; 59 \mathrm{~d}: \mathrm{R}=2-\mathrm{CN}$.

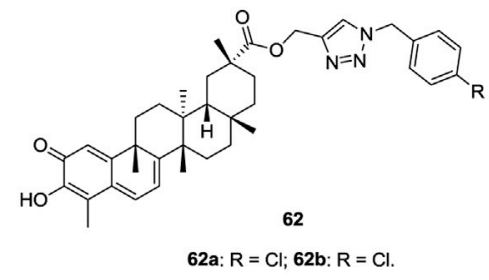

FIGURE 10 | Chemical structures of 1,2,3-triazole-containing steroid derivatives 58-62.

The majority of 1,2,3-triazole-tethered azidothymidine-quinazoline hybrids $\left(\mathrm{IC}_{50}:>200 \mu \mathrm{m}\right.$, MTT assay) are devoid of activity against SK-Lu-1 NSCLC, whereas the activity of hybrid $\mathbf{5 6}\left(\mathrm{IC}_{50}: 9.06 \mu \mathrm{m}\right.$, MTT assay) is at the same level as that of ellipticine $\left(\mathrm{IC}_{50}: 1.30 \mu \mathrm{m}\right)$, and 3.4 times higher than that of erlotinib hydrochloride ( $\mathrm{IC}_{50}: 31.15 \mu \mathrm{m}$ ) (Giang et al., 2018). The 1,2,3-triazole-tethered nucleoside-theophylline hybrids 57a,b ( $\mathrm{IC}_{50}$ : 1.56 and $2.89 \mu \mathrm{m}$, MTT assay) also display certain activity against A549 cells, but the activity is considerably inferior to that of combretastatin-A4 ( $\mathrm{IC}_{50}$ : $0.11 \mu \mathrm{m})$ (Ruddarraju et al., 2016; Trznadel et al., 2019).

\section{1,2,3-TRIAZOLE-CONTAINING STEROID DERIVATIVES}

Steroids that are ubiquitous in natural resources are involved in several physiological functions and exhibit low cytotoxicity, high bioavailability, and excellent efficiency against diverse cancers, including lung cancers (Tantawy et al., 2017; Xiao et al., 2020). Thus, combination of 1,2,3-triazole with steroid is an attractive strategy to develop novel anticancer drug candidates.

1,2,3-Triazole-containing betulinic acid derivatives $\mathbf{5 8}$ (Figure 10, $\mathrm{IC}_{50}: 3.7-9.0 \mu \mathrm{m}$, MTT assay) show promising cytotoxic potential against A549 cells, and the activity is higher than that of the parent betulinic acid $\left(\mathrm{IC}_{50}: 23.0 \mu \mathrm{m}\right)$ (Khan et al., 2016; Dangroo et al., 2017; Grishko et al., 2017). An SAR study suggested that hydrogen bond donors, such as hydroxyl and carboxylic acid, at the meta position of the phenyl ring on the N-1 position of the 1,2,3-triazole moiety are beneficial for their activity. Further studies demonstrated that compound 58a could arrest the G1 phase of the cell cycle and induce apoptosis, which confers its anti-invasive and antimetastatic behavior toward cancer cells. An antiproliferative
SAR study of 1,2,3-triazole-containing diosgenin derivatives $59\left(\mathrm{IC}_{50}: 5.54-31.00 \mu \mathrm{m}, \mathrm{MTT}\right.$ assay) against A549 cells indicates that introduction of electron-donating or electronwithdrawing groups into the phenyl ring is detrimental to the activity (Masood-Ur-Rahman et al., 2017). Among them, four compounds 59a-d $\left(\mathrm{IC}_{50}: 5.54-7.23 \mu \mathrm{m}\right)$ are comparable to BEZ$235\left(\mathrm{IC}_{50}: 6.52 \mu \mathrm{m}\right)$ but more potent than diosgenin $\left(\mathrm{IC}_{50}\right.$ : $13.3 \mu \mathrm{m})$. Most 1,2,3-triazole-containing dehydroepiandrosterone derivatives $60 \quad\left(\mathrm{IC}_{50}\right.$ : $7.6-75.2 \mu \mathrm{m}$, MTT assay) are active against A549 cells, and these compounds exert antiproliferative effects by arresting cells in the G2 phase of the cell cycle and inducing apoptosis (Huang et al., 2018).

1,2,3-Triazole-containing asiatic acid derivatives 61 ( $\mathrm{IC}_{50}$ : 2.67-39.87 $\mu \mathrm{m}$, MTT assay) show promising activity against A549, NCI-H460, and NCI-H460/DOX lung cancer cell lines, and an SAR study reveals that the electron-withdrawing group at the ortho position of the phenyl ring is favorable to the activity (Huang et al., 2019). The representative compound 61a $\left(\mathrm{IC}_{50}\right.$ : $2.67-4.84 \mu \mathrm{m})$ is the most active against the three tested lung cancer cell lines, and the RI value is 1.08, suggesting its potential to fight against drug-resistant lung cancer. Moreover, compound 61a $\left(\mathrm{IC}_{50}:>50 \mu \mathrm{m}\right)$ is nontoxic toward normal HL-7702 cells, and the SI values are $>10.3$. Mechanistic studies illustrate that compound 61a is a potential NF- $\kappa B$ inhibitor and could induce apoptosis and suppress cell migration. Accordingly, rational design of 1,2,3-triazole-containing asiatic acid derivatives may offer a new class of NF- $\kappa$ B inhibitors with the ability to suppress cancer cell migration and induce apoptosis.

Apart from the 1,2,3-triazole-containing steroid derivatives discussed above, some other derivatives also possess certain activity against lung cancer cell lines (Zhu et al., 2015; Zhang et al., 2018; Popov et al., 2020; Treyakova et al., 2020). 1,2,3Triazole-containing celastrol derivatives $\mathbf{6 2 a}, \mathbf{b} \quad\left(\mathrm{IC}_{50}\right.$ : 


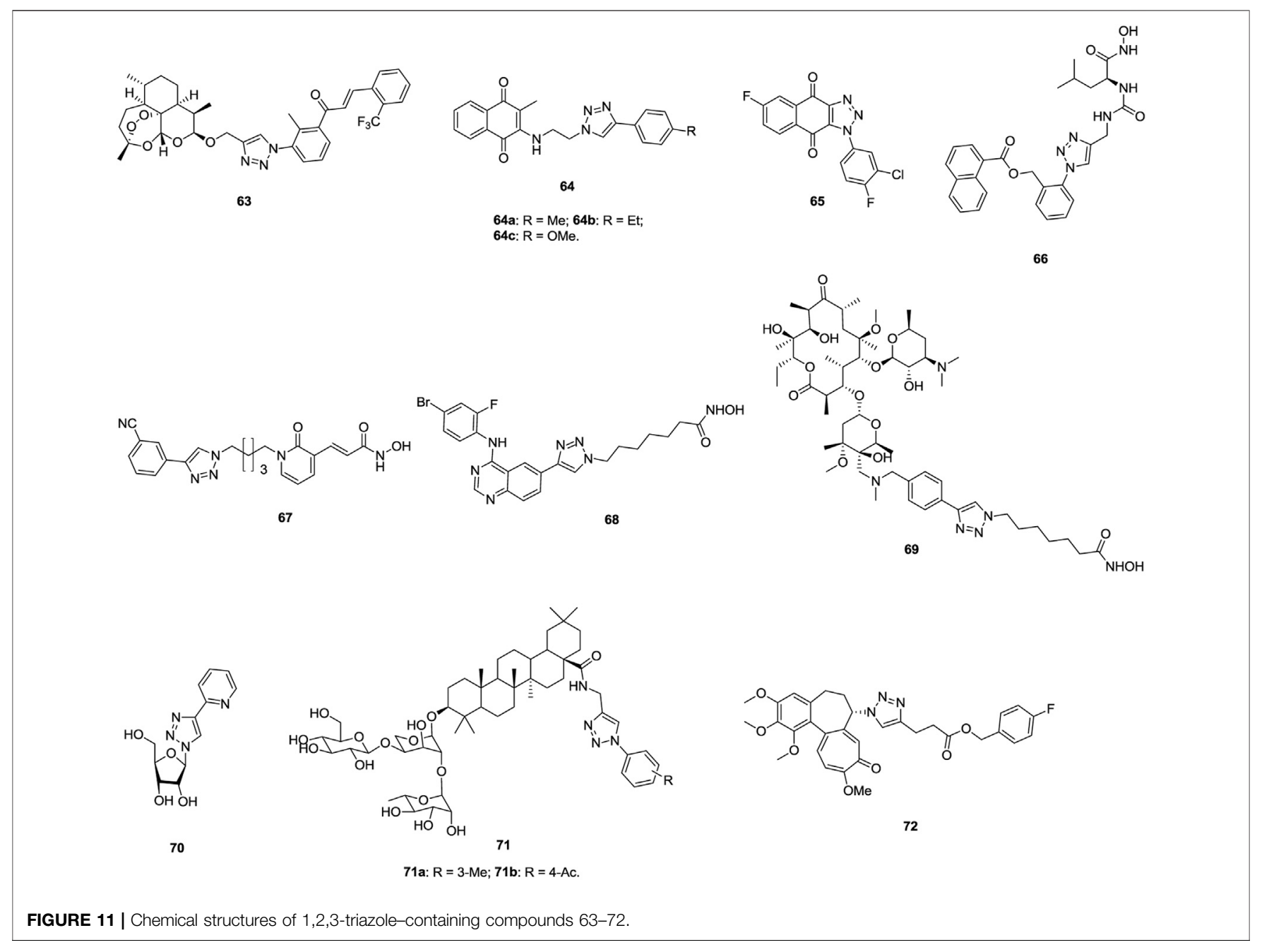

0.97-54.94 $\mu \mathrm{m}$, MTT assay) show broad-spectrum antiproliferative activity, and compound $\mathbf{6 2 a}\left(\mathrm{IC}_{50}: 3.53 \mu \mathrm{m}\right)$ is comparable to celastrol ( $\mathrm{IC}_{50}: 3.02 \mu \mathrm{m}$ ) against A549 cells (Zhang et al., 2018). An SAR study demonstrates that the 1,2,3-triazole moiety is not essential for the activity and that the removal of this moiety exerts minimal influence on the activity.

\section{MISCELLANEOUS 1,2,3-TRIAZOLE-CONTAINING COMPOUNDS}

1,2,3-Triazole-tethered dihydroartemisinin-chalcone hybrid $\mathbf{6 3}$ (Figure 11, $\mathrm{IC}_{50}: 7.16 \mu \mathrm{m}$, MTT assay) display comparable activity to doxorubicin $\left(\mathrm{IC}_{50}: 6.36 \mu \mathrm{m}\right.$ ), but it is more potent than dihydroartemisinin ( $\left.\mathrm{IC}_{50}: 43.43 \mu \mathrm{m}\right)$ against $\mathrm{A} 549$ cells, and this hybrid $\left(\mathrm{IC}_{50}:>100 \mu \mathrm{m}\right)$ is nontoxic toward human erythrocyte and normal kidney cells (HEK-293) (Kapkoti et al., 2018). An SAR study implies that incorporation of the second dihydroartemisinin moiety could boost the activity to some extent. Mechanistic studies reveal that hybrid 63 significantly induces the ROS formation in A549 cells and causes cell cycle arrest at the G2/M phase as well as apoptosis in cancer cells.

1,2,3-Triazole-containing naphthoquinones $64 \quad\left(\mathrm{IC}_{50}\right.$ : 8.33-84.14 $\mu \mathrm{m}$, MTT assay) show considerable activity against A549 cells, and an SAR study demonstrated that the alkyl or alkyloxy group at the para position of the phenyl ring has advantages to the activity (Prasad et al., 2018). Among them, compound 64b $\left(\mathrm{IC}_{50}: 9.19 \mu \mathrm{m}\right)$ is slightly more active than tamoxifen $\left(\mathrm{IC}_{50}: 10.87 \mu \mathrm{m}\right)$, and it could arrest the cell cycle at the G0/G1 phase and induce apoptotic cell death. Accordingly, compound $\mathbf{6 4 b}$ could be taken as a lead molecule for further development of potent anti-lung cancer therapeutic agents. In LL2 (Lewis lung cancer, bearing a high expression level of IDO1) and Hepa1-6-xenografted mouse models, compound $\mathbf{6 5}$ $(30 \mathrm{mg} / \mathrm{kg}$, intraperitoneally) demonstrates moderate in vivo anticancer efficacy with TGI rates of $62.5 \%$ and $80 \%$, and the potency is higher than that of epacdostat (TGI: 50.0\%) (Pan et al., 2020). Moreover, in vivo experiments reveal no obvious body 


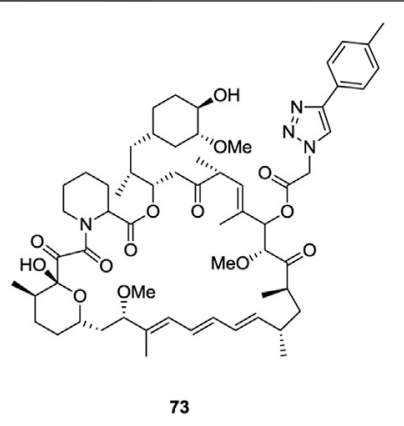

73<smiles></smiles>

78



82a: $R=F ; 82 b: R=N_{2}$

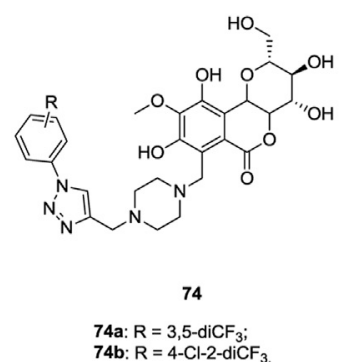

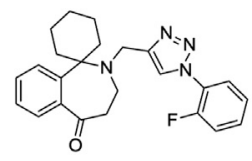

75<smiles>[R]c1cccc(-n2cc(CN3CC(O)c4ccccc4C34CCCCC4)nn2)c1</smiles>

$76 a: R=3-F ;$
$76 b: R=2-O M=$

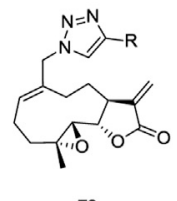

79

79a: $\mathrm{R}=4-\mathrm{CIPh} ;$

79b: $\mathrm{R}=4-\mathrm{OMePh}$

79c: $\mathrm{R}=4-\mathrm{FPOCH}_{2}$

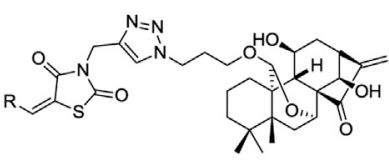

80



80a: $R=$ Me; 80b: $R=$ n-amy



77a: $R=$ TIPS; 77b: $R=3-O B n-4-O M e B n$.
81

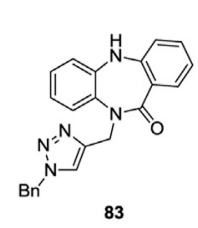

FIGURE 12 | Chemical structures of 1,2,3-triazole-containing compounds 73-83.

weight change, implying its excellent safety profile. Therefore, compound 65 could serve as a preclinical candidate for further evaluations.

1,2,3-Triazole-containing hydroxamic acid $66\left(\mathrm{IC}_{50}: 57.5 \mu \mathrm{m}\right.$, MTT assay) not only displays comparable activity to 5fluorouracil $\left(\mathrm{IC}_{50}: 37.9 \mu \mathrm{m}\right)$ against $\mathrm{A} 549$ cells but also exhibits synergistic effect with 5-fluorouracil ( $\mathrm{IC}_{50}: 16.6 \mu \mathrm{m}$ ) (Cao et al., 2019). Further studies showed that compound $66\left(\mathrm{IC}_{50}: 32 \mathrm{nM}\right)$ is a potential aminopeptidase $\mathrm{N}$ inhibitor, and it is nontoxic toward normal HUVECs $\left(\mathrm{IC}_{50}\right.$ : $\left.>2000 \mu \mathrm{m}\right)$. In addition, in the $\mathrm{H} 22$ xenografted mouse model, compound 66 alone or in combination with 5-fluorouracil could effectively inhibit tumor growth without causing loss of body weight. 1,2,3-Triazole-tethered dihydropyridin-2-one-hydroxamic acid hybrid 67 ( $\mathrm{IC}_{50}: 35$ and $49 \mathrm{nM}$ ) is a potential HDAC1 and HDAC6 inhibitor, and it ( $\mathrm{IC}_{50}: 8.8 \mu \mathrm{m}, \mathrm{MTT}$ assay) is as potent as SAHA ( $\left.\mathrm{IC}_{50}: 8.9 \mu \mathrm{m}\right)$ against A549 cells ( $\mathrm{Li}$ and $\mathrm{Han}, 2016)$. Moreover, hybrid 67 (IC $\mathrm{IO}_{50}$ : $>50 \mu \mathrm{m})$ is nontoxic toward normal RWPE-1 and VERO cells, and $\mathrm{SI}>$ 5.6. Compound 68 reveals outstanding potency $\left(\mathrm{IC}_{50}\right.$ : 1.1-10.3 nM) against EGFR, HDAC1, and HDAC6 and promising activity ( $\mathrm{IC}_{50}: 0.71$ and $7.85 \mu \mathrm{m}$, MTT assay) against A549 and NCI-H1975 lung cancer cell lines, and its antiproliferative activity is also superior to that of vorinostat
$\left(\mathrm{IC}_{50}: 2.67\right.$ and $23.76 \mu \mathrm{m}$ ) (Ding et al., 2017). Thus, this compound could act as a potential candidate for clinical applications. 1,2,3-Triazole-tethered clarithromycinhydroxamic acid hybrid 69 ( $\mathrm{IC}_{50}: 23.9$ and $2.85 \mathrm{nM}$ ) demonstrates excellent inhibitory activity against HDAC1 and HDAC6, and the activity of this hybrid $\left(\mathrm{IC}_{50}: 0.99\right.$ and $0.69 \mu \mathrm{m}$, MTT assay) is around five-fold higher than that of SAHA ( $\mathrm{IC}_{50}$ : 5.00 and $3.27 \mu \mathrm{m}$ ) against A549 cells (Tapadar et al., 2015).

Some 1,2,3-triazole-containing sugar derivatives also possess certain antiproliferative activity against lung cancer cell lines (Petrova et al., 2015; Nagarsenkar et al., 2016; Li et al., 2018; Jakukowski et al., 2020; Tsai et al., 2020; Zi et al., 2020), and 1,2,3triazole-tethered $\beta$-D-ribofuranose-pyridine hybrid $70 \quad\left(\mathrm{IC}_{50}\right.$ : $17.7 \mu \mathrm{m}$, MTT assay) is 3.4 -fold more potent than cisplatin $\left(\mathrm{IC}_{50}: 17.7 \mu \mathrm{m}\right)$ against A549 cells (Jakukowski et al., 2020), whereas hybrids 71 ( $\mathrm{IC}_{50}: 0.18-54.89 \mu \mathrm{m}$, MTT assay) are more active than 5-fluorouracil ( $\mathrm{IC}_{50}: 69.07 \mu \mathrm{m}$ ) ( $\mathrm{Li}$ et al., 2018). An SAR study suggests that the electron-donating group benefits the activity compared with the electronwithdrawing group on the phenyl ring, and replacement of the phenyl ring by the pyridinyl ring results in significant loss of activity. In particular, hybrids $7 \mathbf{1 a , b}\left(\mathrm{IC}_{50}: 0.18\right.$ and $\left.0.28 \mu \mathrm{m}\right)$ are highly potent against A549 cells, and mechanistic investigations 
demonstrate that these hybrids could inhibit the proliferation by inducing apoptosis and arresting the cell cycle at the G1 and S phases.

1,2,3-Triazole-containing colchicine derivative $72 \quad\left(\mathrm{IC}_{50}\right.$ : $3.5 \mathrm{nM}$, MTT assay) shows remarkable cytotoxic efficacy against A549 cells, and the activity is 3.7-fold higher than that of paclitaxel $\left(\mathrm{IC}_{50}: 13.2 \mathrm{nM}\right)$, revealing the potential of $1,2,3-$ triazole-containing colchicine derivatives as novel anti-lung cancer candidates (Thomopoulou et al., 2016).

1,2,3-Triazole-containing rapamycin derivatives $\left(\mathrm{IC}_{50}\right.$ : 12.4-17.9 $\mu \mathrm{m}$, MTT assay) show higher activity than the parent rapamycin $\left(\mathrm{IC}_{50}: 18.1 \mu \mathrm{m}\right)$ against $\mathrm{A} 549$ cells, and compound 73 (Figure 12, $\mathrm{IC}_{50}: 12.8 \mu \mathrm{m}$ ) could induce apoptosis and cell cycle arrest in A549 cells (Huang et al., 2018). Moreover, compound 73 inhibits the phosphorylation of mTOR and its downstream key kinases 4EBP1 and p70S6K1 in A549 cells, revealing that this compound could also display effective inhibitory effect on the mTORC1 signaling pathway as rapamycin. Accordingly, compound $\mathbf{7 3}$ has the potential to be developed as a new mTOR inhibitor against lung cancers.

1,2,3-Triazole-containing bergenin derivatives $74 \quad\left(\mathrm{IC}_{50}\right.$ : 1.86-23.05 $\mu \mathrm{m}$, MTT assay) are endowed with considerable activity against A549 cells, and an SAR study demonstrates that the trifluoromethyl group on the phenyl ring is beneficial for the activity (Kumar et al., 2019). In particular, compound 74a ( IC $_{50}: 1.86 \mu \mathrm{m}$, MTT assay), which is comparable to doxorubicin $\left(\mathrm{IC}_{50}: 1.98 \mu \mathrm{m}\right)$, demonstrates potent activity. Cell cycle analysis show that compound 74a could induce G2/M phase arrest and lead to the accumulation of cyclin B1 protein. Cell-based tubulin polymerization assays and docking studies implies that compound 74a disrupts tubulin assembly by occupying the colchicine binding pocket of tubulin.

1,2,3-Triazole-containing homoerythrina derivative $75\left(\mathrm{IC}_{50}\right.$ : $1.89 \mu \mathrm{m}$, MTT assay) has excellent inhibitory activity to A549 cells, which is higher than those of pemetrexed $\left(\mathrm{IC}_{50}: 3.39 \mu \mathrm{m}\right)$, rucaparib $\left(\mathrm{IC}_{50}: 4.91 \mu \mathrm{m}\right)$, and harringtonine $\left(\mathrm{IC}_{50}: 10.55 \mu \mathrm{m}\right)(\mathrm{Li}$ et al., 2020). 1,2,3-Triazole-containing erythrina derivatives 76a,b ( $\mathrm{IC}_{50}$ : 0.94 and $0.98 \mu \mathrm{m}$, MTT assay) show enhanced activity against $\mathrm{A} 549$ cells, and the activity is $\sim 5$ times superior to that of rucaparib ( $\mathrm{IC}_{50}: 4.69 \mu \mathrm{m}$ ) (Li et al., 2020). Flow cytometry analysis shows that these hybrids not only significantly arrest the cell cycle in the $\mathrm{S}$ phase but also induce the apoptosis of the cells. Further studies suggests that these compounds could inhibit the expression of cyclin A, downregulate the expression of bcl-2/bax, activate caspase-3, and ultimately induce the apoptosis of A549 cells.

A significant part of 1,2,3-triazole-containing methoxygenipin derivatives 77 ( $\mathrm{IC}_{50}: 4.53-47.18 \mu \mathrm{m}$, SRB assay) are active against A549 cells, whereas the parent genipin $\left(\mathrm{IC}_{50}\right.$ : $>20.0 \mu \mathrm{m}$ ) is devoid of activity (Silalai et al., 2020). An SAR study implies that the introduction of dibenzyl ether substituted silyl and long-chain aliphatic groups into the C10 position of the genipin moiety could increase the activity. Compounds 77a,b $\left(\mathrm{IC}_{50}: 4.81\right.$ and $\left.4.53 \mu \mathrm{m}\right)$ are the most active against A549 cells. Thus, both of them merit further investigations. 1,2,3-Triazole-containing bavachinin derivative
78 ( $\mathrm{IC}_{50}: 7.72 \mu \mathrm{m}, \mathrm{SRB}$ assay) is more potent than bavachinin $\left(\mathrm{IC}_{50}: 30.5 \mu \mathrm{m}\right)$ against $\mathrm{A} 549$ cells, and a mechanistic study reveals that this compound could induce apoptotic cell death through loss of MMP and PARP cleavage (Gupta et al., 2018). Compound $\mathbf{7 8}$ could also inhibit the colony formation, cell migration, and induce the morphological changes concentration-dependently.

1,2,3-Triazole-containing melampomagnolide $\mathrm{B}$ derivatives $79 \mathrm{IC}_{50}: 1.17-34.13 \mu \mathrm{m}$, MTT assay) show considerable activity against A549 cells, and most of them are more potent than the parent melampomagnolide $\mathrm{B}\left(\mathrm{IC}_{50}: 9.94 \mu \mathrm{m}\right)$ (Ding et al., 2018). The representative compound 79d $\left(\mathrm{IC}_{50}\right.$ : $1.35 \mu \mathrm{m}$ ) shows significant efficacy by inducing apoptosis, inhibiting the proliferation and migration of cancer cells. Thus, this compound might be considered as a promising anticancer drug candidate for further evaluation. 1,2,3Triazole-tethered Jiyuan Oridonin A-thiazolin-dione hybrids 80a,b ( $\mathrm{IC}_{50}$ : 3.5 and $4.8 \mu \mathrm{m}$, MTT assay) demonstrates higher activity than Jiyuan Oridonin $\mathrm{A}\left(\mathrm{IC}_{50}: 16.4 \mu \mathrm{m}\right)$ against A549 cells, and further mechanistic studies reveals that hybrid 80a has inhibition on the proliferation of cancer cells by inducing apoptosis and arresting the cell cycle at the G1 phase (Ke et al., 2018).

1,2,3-Triazole-containing L-ascorbic acid derivative $\mathbf{8 1}\left(\mathrm{IC}_{50}\right.$ : $0.75-9.42 \mu \mathrm{m}$, MTT assay) possesses excellent antiproliferative activity against A549 cells, whereas the parent L-ascorbic acid $\left(\mathrm{IC}_{50}:>100 \mu \mathrm{m}\right)$ is inactive, suggesting that 1,2,3triazole-containing L-ascorbic acid derivatives may be promising for the discovery of novel anti-lung cancer agents (Harej et al., 2019; Macan et al., 2019).

1,2,3-Triazole-containing phosphonate derivatives $\mathbf{8 2 a}, \mathbf{b}$ $\left(\mathrm{IC}_{50}: 2.0\right.$ and $3.0 \mu \mathrm{m}$, MTT assay) show potential activity against A549 cells, and the activity is superior to that of doxorubicin $\left(\mathrm{IC}_{50}: 4.4 \mu \mathrm{m}\right)$, revealing that these compounds warrant further investigations (Makarov et al., 2015). Additionally, the activity of 1,2,3-triazole-containing dibenzo $[\mathrm{b}, \mathrm{e}][1,4]$ diazepin-11-one hybrid $83\left(\mathrm{IC}_{50}: 0.71 \mu \mathrm{m}, \mathrm{MTT}\right.$ assay) against A549 cells is much higher than that of 5fluorouracil $\left(\mathrm{IC}_{50}: 3.47 \mu \mathrm{m}\right)$, and this hybrid could induce the G2/M phase of cell cycle arrest and apoptosis, indicating that hybrid 83 could be used for further studies as anti-lung cancer candidates (Praveen Kumar et al., 2016).

Some other compounds which are combined by 1,2,3-triazole and benzodiazepine/benzoxepine/dithiocarbamate/ deoxysalinomycin/myrrhanone B/phenanthrene/pyrano(2,3-c) phenazine/paeonol/naphthalimide/sesquiterpene/sulfonate ester/sapinofuranone/triterpene/thiourea/benzothiazinone/ benzoxazinone/furan/nimesulide (Kuntala et al., 2015; Poornima et al., 2015; Sudhapriya et al., 2015; Chandrashekhar et al., 2016; Reddy et al., 2016; Shaikh et al., 2016; Abdallah et al., 2017; Battula et al., 2017; Kumar et al., 2017; Lu et al., 2017; Mareddy et al., 2017; Mo et al., 2017; Nguyen et al., 2017; Li et al., 2018; Narsimha et al., 2018; Ou et al., 2019; Yang et al., 2019; Jiang et al., 2020; Kanabar et al., 2020; Madasu et al., 2020; Qi et al., 2020; Zhang et al., 2020) also possess certain activity against lung cancer cell lines, but their activities are generally far inferior to those of the references. Hence, these derivatives still need further structural modifications. 


\section{CONCLUSIONS}

Lung cancer, as a cancer with the highest morbidity, is the leading cause of cancer-related deaths and has already posed heavy burden on the world health system, which makes an urgent need to develop novel anti-lung cancer agents. 1,2,3-Triazole could readily interact with diverse enzymes and receptors in organisms through weak interaction and has been considered as a privileged structure in medicinal chemistry. 1,2,3-Triazole-containing agent CAI synergizes with sorafenib to combat NSCLC through the inhibition of NANOG and aggravation of apoptosis, indicating that 1,2,3-triazole-containing derivatives are useful scaffolds to develop novel anti-lung cancer agents.

The azide-alkyne cycloaddition reaction is the major strategy to synthesize 1,2,3-triazoles. The thermal Huisgen 1,3-dipolar cycloaddition usually results in poor regioselectivity, but the Huisgen cycloaddition catalyzed by metal catalyst could give excellent regioselectivity. For example, the copper(I)-catalyzed azide-alkyne cycloaddition (CuAAC) usually affords 1,4disubstituted 1,2,3-triazoles, whereas ruthenium(II)-catalyzed azide-alkyne cycloaddition often provides 1,5-disubstituted triazoles. However, azides are energy-rich and potentially explosive substances, so synthesis of azides should be careful. Even though various 1,2,3-triazoles showed poor solubility, combination of the 1,2,3-triazole moiety with the other pharmocophores demonstrated good soluability, and may solve the issue of solubility.

This review summarizes the current developments, mechanisms of action and SAR of a series of 1,2,3triazole-containing derivatives (chromene/coumarin, chalcone,

\section{REFERENCES}

Abdallah, W., Znati, M., Regazzetti, A., Dargère, D., Laprévote, O., Ben Jannet, H., et al. (2017). Synthesis of S-Mono- and S,O-bis-1,2,3-triazole Linked 1,5benzodiazepine Conjugates and Evaluation of Their Cytotoxic, Antityrosinase, and Anti-cholinesterase Activities. Phosphorus, Sulfur, Silicon Relat. Elem. 192 (7), 835-844. doi:10.1080/10426507.2017.1287704

Al-Warhi, T., Sabt, A., Elkaeed, E. B., and Eldehna, W. M. (2020). Recent Advancements of Coumarin-Based Anticancer Agents: An Up-To-Date Review. Bioorg. Chem. 103, e104163. doi:10.1016/j.bioorg.2020.104163

Bade, B. C., and Dela Cruz, C. S. (2020). Lung Cancer 2020. Clin. Chest Med. 41 (1), 1-24. doi:10.1016/j.ccm.2019.10.001

Battula, K. S., Narsimha, S., Thatipamula, R. K., Reddy, Y. N., and Nagavelli, V. R. (2017). Synthesis and Biological Evaluation of (N-(3-methoxyphenyl)-4-((aryl1H -1,2,3-Triazol-4-Yl)methyl)thiomorpholine-2-Carboxamide 1,1-Dioxide Hybrids as Antiproliferative Agents. ChemistrySelect 2, 9595-9598. doi:10. 1002/slct.201701902

Bistrovic, A., Grbcic, P., Harej, A., Sedic, M., Kraljevic-Pavelic, S., Kostrun, S., et al. (2018). Small Molecule Purine and Pseudopurine Derivatives: Synthesis, Cytostatic Evaluations and Investigation of Growth Inhibitory Effect in Non-small Cell Lung Cancer A549. J. Enzym. Inhib. Med. Chem. 33, 271-285. doi:10.1080/14756366.2017.1414807

Boda, S. K., Pishka, V., Lakshmi, A., Chinde, S., and Grover, P. (2018). 1,2,3-Triazole Tagged 3H-Pyrano[2,3-D]pyrimidine-6-Carboxylate Derivatives: Synthesis, In Vitro Anticancer Activity, Molecular Docking and DNA Interaction Studies. Chem. Biodiver. 15, e18000101. doi:10.1002/cbdv.201800101

Bonandi, E., Christodoulou, M. S., Fumagalli, G., Perdicchia, D., Rastelli, G., and Passarella, D. (2017). The 1,2,3-triazole Ring as a Bioisostere in Medicinal 1,2,3-triazole-indole, quinoline/quinolone,

podophyllotoxin/epipodophyllotoxin, nucleoside, and steroid derivatives), and some of them suggest great in vitro and in vivo efficacy. Overall, rational design of 1,2,3triazole-containing derivatives may provide novel anticancer agents with excellent potency against various lung cancers, including drug-resistant forms.

\section{AUTHOR CONTRIBUTIONS}

TL, FG, and GH wrote section 1-6. WL and XS wrote section 7-11. FG and GH collected the whole manuscript. TL and XS corrected the manuscript. All authors read and approved the final manuscript.

\section{FUNDING}

This research was funded by grants from the National Natural Science Foundation of China (81371601) and the Natural Science Foundation of Shandong Province (ZR2019MH019, ZR2019BA015), and also got the support from Science \& Technology Department of Sichuan Province (2019YJ0674).

\section{ACKNOWLEDGMENTS}

This work gained great support by core facilities sharing platform of Shandong University.

Chemistry. Drug Discov. Today 22 (10), 1572-1581. doi:10.1016/j.drudis.2017. 05.014

Boratynski, P. J., Galezowska, J., Turkowiak, K., Anisiewicz, A., Kowalczyk, R., and Wietrzyk, J. (2018). Triazole Biheterocycles from Cinchona Alkaloids: Coordination and Antiproliferative Properties. ChemistrySelect 3, 9368-9373. doi:10.1002/slct.201801810

Bozorov, K., Zhao, J., and Aisa, H. A. (2019). 1,2,3-Triazole-containing Hybrids as Leads in Medicinal Chemistry: A Recent Overview. Bioorg. Med. Chem. 27 (16), 3511-3531. doi:10.1016/j.bmc.2019.07.005

Caeeeiro, E. P., Sena, A. M., Puerta, A., Padron, J. M., and Burke, A. J. (2020). Synthesis of Novel 1,2,3-Triazole-Dihydropyrimidinone Hybrids Using Multicomponent 1,3-dipolar Cycloaddition (Click)-Ciginelli Reactions: Anticancer Activity. Synlett 31, 615-621. doi:10.1055/s-0039-1690781

Cao, J., Zang, J., Kong, X., Zhao, C., Chen, T., Ran, Y., et al. (2019). Leucine Ureido Derivatives as Aminopeptidase $\mathrm{N}$ Inhibitors Using Click Chemistry. Part II. Bioorg. Med. Chem. 27, 978-990. doi:10.1016/j.bmc. 2019.01 .041

Chandrashekhar, M., Nayak, V. L., Ramakrishna, S., and Mallavadhani, U. V. (2016). Novel Triazole Hybrids of Myrrhanone C, a Natural Polypodane Triterpene: Synthesis, Cytotoxic Activity and Cell Based Studies. Eur. J. Med. Chem. 114, 293-307. doi:10.1016/j.ejmech.2016.03.013

Chen, C., Ju, R., Shi, J., Chen, W., Sun, F., Zhu, L., et al. (2017). Carboxyamidotriazole Synergizes with Sorafenib to Combat Non-small Cell Lung Cancer through Inhibition of NANOG and Aggravation of Apoptosis. J. Pharmacol. Exp. Ther. 362 (2), 219-229. doi:10.1124/jpet.117.240986

Chen, R., Zhang, H., Ma, T., Xue, H., Miao, Z., Chen, L., et al. (2019). Moxifloxacin/ Gatifloxacin-1,2,3-triazole-isatin Hybrids with Hydrogen-Bond Donor and Their In Vitro Anticancer Activity. J. Heterocyclic Chem. 56, 2691-2694. doi:10.1002/jhet.3670 
Chinthala, Y., Thakur, S., Tirunagari, S., Chinde, S., Domatti, A. K., Arigari, N. K., et al. (2015). Synthesis, Docking and ADMET Studies of Novel Chalcone Triazoles for Anti-cancer and Anti-diabetic Activity. Eur. J. Med. Chem. 93, 564-573. doi:10.1016/j.ejmech.2015.02.027

Chu, X.-M., Wang, C., Wang, W.-L., Liang, L.-L., Liu, W., Gong, K.-K., et al. (2019). Triazole Derivatives and Their Antiplasmodial and Antimalarial Activities. Eur. J. Med. Chem. 166, 206-223. doi:10.1016/j.ejmech.2019.01.047

Coakley, M., and Popat, S. (2020). Management of Lung Cancer. Medicine 48 (4), 273-278. doi:10.1016/j.mpmed.2020.01.003

Dangroo, N. A., Singh, J., Rath, S. K., Gupta, N., Qayum, A., Singh, S., et al. (2017). A Convergent Synthesis of Novel Alkyne-Azide Cycloaddition Congeners of Betulinic Acid as Potent Cytotoxic Agent. Steroids 123, 1-12. doi:10.1016/j. steroids.2017.04.002

Dasari, S. R., Tondepu, S., Vadali, L. R., and Seelam, N. (2019). Retracted : Design, Synthesis and Molecular Modeling of Nonsteroidal Anti-inflammatory Drugs Tagged Substituted 1,2,3-Triazole Derivatives and Evaluation of Their Biological Activities. J. Heterocyclic Chem. 56, 1318-1329. doi:10.1002/jhet.3503

Dhawan, S., Awolade, P., Kisten, P., Cele, N., Pillay, A. S., Saha, S., et al. (2020). Synthesis, Cytotoxicity and Antimicrobial Evaluation of New CoumarinTagged $\beta$-lactam Triazole Hybrid. Chem. Biodiver. 17, e1900462. doi:10. 1002/cbdv.201900462

Diao, Q. P., Guo, H., and Wang, G. Q. (2019). Design, Synthesis, and In Vitro Anticancer Activities of Diethylene Glycol Tethered Isatin-1,2,3-triazolecoumarin Hybrids. J. Heterocyclic Chem. 56, 1667-1671. doi:10.1002/jhet.3538

Ding, C., Li, D., Wang, Y.-W., Han, S.-S., Gao, C.-M., Tan, C.-Y., et al. (2017). Discovery of ErbB/HDAC Inhibitors by Combining the Core Pharmacophores of HDAC Inhibitor Vorinostat and Kinase Inhibitors Vandetanib, BMS690514, Neratinib, and TAK-285. Chin. Chem. Lett. 28, 1220-1227. doi:10. 1016/j.cclet.2017.01.003

Ding, Y., Guo, H., Ge, W., Chen, X., Li, S., Wang, M., et al. (2018). Copper(I) Oxide Nanoparticles Catalyzed Click Chemistry Based Synthesis of Melampomagnolide B-Triazole Conjugates and Their Anti-cancer Activities. Eur. J. Med. Chem. 156, 216-229. doi:10.1016/j.ejmech.2018.06.058

Fan, Y. L., Huang, Z. P., and Liu, M. (2018). Design, Synthesis and Antitumor Activities of 1,2,3-triazole-diethylene Glycol Tethered Isatin Dimers. J. Heterocyclic Chem. 55, 2990-2995. doi:10.1002/jhet.3330

Farrer, N. J., and Griffith, D. M. (2020). Exploiting Azide-Alkyne Click Chemistry in the Synthesis, Tracking and Targeting of Platinum Anticancer Complexes. Curr. Opin. Chem. Biol. 55, 59-68. doi:10.1016/j.cbpa.2019.12.001

Feng, L. S., Xu, Z., Chang, L., Li, C., Yan, X. F., Gao, C., et al. (2020). Hybrid Molecules with Potential In Vitro Antiplasmodial and In Vivo Antimalarial Activity against Drug-resistant Plasmodium Falciparum. Med. Res. Rev. 40 (3), 931-971. doi:10.1002/med.21643

Feng, L. S., Zheng, M. J., Zhao, F., and Liu, D. (2021). 1,2,3-Triazole Hybrids with Anti-HIV-1 Activity. Arch. Pharm. 354 (1), e2000163. doi:10.1002/ardp. 202000163

Ferreira, V. F., Da Rocha, D. R., Da Silva, F. C., Ferreira, P. G., Boechat, N. A., and Magalhães, J. L. (2013). Novel 1H-1,2,3-, 2H-1,2,3-, 1H-1,2,4- and 4H-1,2,4Triazole Derivatives: a Patent Review (2008 - 2011). Expert Opin. Ther. Patents 23 (3), 319-331. doi:10.1517/13543776.2013.749862

Gao, F., Huang, G., and Xiao, J. (2020). Chalcone Hybrids as Potential Anticancer Agents: Current Development, Mechanism of Action, and Structure-activity Relationship. Med. Res. Rev. 40 (5), 2049-2084. doi:10.1002/med.21698

Geng, P.-F., Liu, X.-Q., Zhao, T.-Q., Wang, C.-C., Li, Z.-H., Zhang, J., et al. (2018). Design, Synthesis and In Vitro Biological Evaluation of Novel $[1,2,3]$ triazolo [4,5-D]pyrimidine Derivatives Containing a Thiosemicarbazide Moiety. Eur. J. Med. Chem. 146, 147-156. doi:10.1016/j.ejmech.2018.01.031

Giang, L. N. T., Nga, N. T., Van, D. T., Anh, D. T. T., Phuong, H. T., Thanh, N. H., et al. (2018). Design, Synthesis and Cytotoxic Evaluation of 4Anilinoquinazoline-Triazole-AZT Hybrids as Anticancer Agents. Nat. Prod. Commun. 13 (12), 1633-1636. doi:10.1177/1934578x1801301215

Goel, R., Luxami, V., and Paul, K. (2016). Imidazo[1,2-a]pyridines: Promising Drug Candidate for Antitumor Therapy. Ctmc 16, 3590-3616. doi:10.2174/ 1568026616666160414122644

Goud, N. S., Pooladanda, V., Mahammad, G. S., Jakkula, P., Gatreddi, S., Qureshi, I. A., et al. (2019). Synthesis and Biological Evaluation of Morpholines Linked Coumarin-Triazole Hybrids as Anticancer Agents. Chem. Biol. Drug Des. 94, 1919-1929. doi:10.1111/cbdd.13578
Gray, M. E., Meehan, J., Sullivan, P., Marland, J. R. K., Greenhalgh, S. N., Gregson, R., et al. (2019). Ovine Pulmonary Adenocarcinoma: A Unique Model to Improve Lung Cancer Research. Front. Oncol. 9, e335. doi:10.3389/fonc.2019.00335

Gregoric, T., Sedic, M., Grbcic, P., Paravic, A. T., Pavelic, S. K., Vetina, M., et al. (2017). Novel Pyrimidine-2,4-Dione-1,2,3-Triazole and Furo[2,3-D] pyrimidine-2-Onee1,2,3-Triazole Hybrids as Potential Anti-cancer Agents: Synthesis, Computational and X-ray Analysis and Biological Evaluation. Eur. J. Med. Chem. 125, 1247-1267. doi:10.1016/j.ejmech.2016.11.028

Grishko, V. V., Tolmacheva, I. A., Nebogatikov, V. O., Galaiko, N. V., Nazarov, A. V., Dmitriev, M. V., et al. (2017). Preparation of Novel Ring-A Fused Azole Derivatives of Betulin and Evaluation of Their Cytotoxicity. Eur. J. Med. Chem. 125, 629-639. doi:10.1016/j.jmech.2016.09.065

Guo, H., and Diao, Q.-P. (2020). The Anti-breast Cancer Potential of Bis-Isatin Scaffolds. Ctmc 20 (16), 1499-1503. doi:10.2174/1568026620666200310124416

Gupta, N., Qayum, A., Raina, A., Shankar, R., Gairola, S., Singh, S., et al. (2018). Synthesis and Biological Evaluation of Novel Bavachinin Analogs as Anticancer Agents. Eur. J. Med. Chem. 145, 511-523. doi:10.1016/j.ejmech.2018.01.006

Hao, S.-Y., Feng, S.-L., Wang, X.-R., Wang, Z., Chen, S.-W., and Hui, L. (2019). Novel Conjugates of Podophyllotoxin and Coumarin: Synthesis, Cytotoxicities, Cell Cycle Arrest, Binding CT DNA and Inhibition of Topo II $\beta$. Bioorg. Med. Chem. Lett. 29, 2129-2135. doi:10.1016/j.bmcl.2019.06.063

Harej, A., Macan, A. M., Stepanic, V., Klobucar, M., Pavelic, K., Pavelic, S. K., et al. (2019). The Antioxidant and Antiproliferative Activities of 1,2,3-Triazolyl-LAscorbic Acid Derivatives. Int. J. Mol. Sci. 20, e4735. doi:10.3390/ijms20194735

He, Z. X., Zhao, T. Q., Gong, Y. P., Zhang, X., Ma, L. Y., and Liu, H. M. (2020). Pyrimidine: A Promising Scaffold for Optimization to Develop the Inhibitors of ABC Transporters. Eur. J. Med. Chem. 200, e112458. doi:10.1016/j.ejmech. 2020.112458

Hou, W., Zhang, G., Luo, Z., Su, L., and Xu, H. (2019). Click Chemistry-based Synthesis and Cytotoxic Activity Evaluation of 4a-triazole Acetate Podophyllotoxin Derivatives. Chem. Biol. Drug Des. 93, 473-483. doi:10. $1111 /$ cbdd. 13436

Huang, Q., Xie, L., Chen, X., Yu, H., Lv, Y., Huang, X., et al. (2018). Synthesis and Anticancer Activity of Novel Rapamycin C-28 Containing Triazole Moiety Compounds. Arch. Pharm. 351, e1800123. doi:10.1002/ardp.201800123

Huang, R.-Z., Liang, G.-B., Li, M.-S., Fang, Y.-L., Zhao, S.-F., Zhou, M.-M., et al. (2019). Synthesis and Discovery of Asiatic Acid Based 1,2,3-triazole Derivatives as Antitumor Agents Blocking NF- $\mathrm{kB}$ Activation and Cell Migration. Med. Chem. Commun. 10, 584-597. doi:10.1039/c8md00620b

Huang, X., Shen, Q. K., Zhang, H. J., Li, J. L., Tian, Y. S., and Quan, Z. S. (2018). Design and Synthesis of Novel Dehydroepiandrosterone Analogues as Potent Antiproliferative Agents. Molecules 23, e2243. doi:10.3390/molecules23092243

Hussaini, S. M. A., Yedla, P., Babu, K. S., Shaik, T. B., Chityal, G. K., and Kamal, A. (2016). Synthesis and Biological Evaluation of 1,2,3-triazole Tethered Pyrazoline and Chalcone Derivatives. Chem. Biol. Drug Des. 88, 97-109. doi:10.1111/cbdd.12738

Jain, A., and Piplani, P. (2019). Exploring the Chemistry and Therapeutic Potential of Triazoles: A Comprehensive Literature Review. Mini Rev. Med. Chem. 19 (16), 1298-1368. doi:10.2174/1389557519666190312162601

Jain, S., Chandra, V., Kumar Jain, P., Pathak, K., Pathak, D., and Vaidya, A. (2019). Comprehensive Review on Current Developments of Quinoline-Based Anticancer Agents. Arabian J. Chem. 12 (8), 4920-4946. doi:10.1016/j. arabjc.2016.10.009

Jakukowski, M., Lakomska, I., Sitkowski, J., Pokrywczynska, M., Dabrowski, P., Framski, G., et al. (2020). Multinuclear Magnetic Resonance Characterization and Antiproliferative Studies of Novel Dichlorido Platinum(II) Complexes Containing Kinetin Riboside and 1- $\beta$-D-Ribofuranosyl-4-(2-Pyridyl)- $1 H$ 1,2,3-Triazole. Polyhedron 180, e114428. doi:10.1016/j.poly.2020.114428

Jiang, D., and Zhang, G. (2019). Ciprofloxacin/Gatifloxacin-1,2,3-triazole-isatin Hybrids and Their In Vitro Anticancer Activity. J. Heterocyclic Chem. 56, 2966-2969. doi:10.1002/jhet.3684

Jiang, Y., Li, Y., Yang, T., Shi, X., Suo, H., Zhang, W., et al. (2020). Design, Synthesis, and Antilung Adenocarcinoma Activity Research of Novel Paeonol Schiff Base Derivatives Containing a 1,2,3-triazole Moiety. J. Chin. Chem. Soc. 67, 165-171. doi:10.1002/jccs.201800491

Kamal, A., Ali Hussaini, S. M., Rahim, A., and Riyaz, S. (2015). Podophyllotoxin Derivatives: A Patent Review (2012 - 2014). Expert Opin. Ther. Patents 25 (9), 1025-1034. doi:10.1517/13543776.2015.1051727 
Kamal, A., Subba Rao, A. V., Vishnuvardhan, M. V. P. S., Srinivas Reddy, T., Swapna, K., Bagul, C., et al. (2015). Synthesis of 2-Anilinopyridyl-Triazole Conjugates as Antimitotic Agents. Org. Biomol. Chem. 13, 4879-4895. doi:10. 1039/c5ob00232j

Kanabar, D., Farrales, P., Kabir, A., Juang, D., Gnanmony, M., Almasri, J., et al. (2020). Optimizing the Aryl-Triazole of Cjoc42 for Enhanced Gankyrin Binding and Anti-cancer Activity. Bioorg. Med. Chem. Lett. 30, e127372. doi:10.1016/j.bmcl.2020.127372

Kandi, S. K., Manohar, S., Vélez Gerena, C. E., Zayas, B., Malhotra, S. V., and Rawat, D. S. (2015). C5-Curcuminoid-4-aminoquinoline Based Molecular Hybrids: Design, Synthesis and Mechanistic Investigation of Anticancer Activity. New J. Chem. 39, 224-234. doi:10.1039/c4nj00936c

Kapkoti, D. S., Singh, S., Luqman, S., and Bhakuni, R. S. (2018). Synthesis of Novel 1,2,3-triazole Based Artemisinin Derivatives and Their Antiproliferative Activity. New J. Chem. 42, 5978-5995. doi:10.1039/c7nj04271j

Karthikeyan, C., Moorthy, N. S., Ramasamy, S., Vanam, U., Manivannan, E., Karunagaran, D., et al. (2015). Advances in Chalcones with Anticancer Activities. Recent Pat. Anticancer Drug Discov. 10, 97-115. doi:10.2174/ 1574892809666140819153902

Ke, Y., Liang, J.-J., Hou, R.-J., Li, M.-M., Zhao, L.-F., Wang, W., et al. (2018). Synthesis and Biological Evaluation of Novel Jiyuan Oridonin A-1,2,3-TriazoleAzole Derivatives as Antiproliferative Agents. Eur. J. Med. Chem. 157, 1249-1263. doi:10.1016/j.ejmech.2018.08.056

Khan, I., Guru, S. K., Rath, S. K., Chinthakindi, P. K., Singh, B., Koul, S., et al. (2016). A Novel Triazole Derivative of Betulinic Acid Induces Extrinsic and Intrinsic Apoptosis in Human Leukemia HL-60 Cells. Eur. J. Med. Chem. 108, 104-116. doi:10.1016/j.ejmech.2015.11.018

Khazir, J., Mir, B. A., Chashoo, G., Pilcher, L., and Riley, D. (2020). Synthesis and Anticancer Activity of N-9- and N-7- Substituted 1,2,3 Triazole Analogues of 2,6-Di-Substituted Purine. Med. Chem. Res. 29, 33-45. doi:10.1007/s00044-01902456-9

Kraljevic, T. G., Harej, A., Sedic, M., Pavelic, S. K., Stepanic, V., Drenjancevic, D., et al. (2016). Synthesis, In Vitro Anticancer and Antibacterial Activities and In Silico Studies of New 4-substituted 1,2,3-Triazole-Coumarin Hybrids. Eur. J. Med. Chem. 124, 794-808.

Kumar, N. P., Nekkanti, S., Sujana Kumari, S., Sharma, P., and Shankaraiah, N. (2017). Design and Synthesis of 1,2,3-Triazolo-Phenanthrene Hybrids as Cytotoxic Agents. Bioorg. Med. Chem. Lett. 27, 2369-2376. doi:10.1016/j. bmcl.2017.04.022

Kumar, P. P., Siva, B., Rao, B. V., Kumar, G. D., Nayak, V. L., Jain, S. N., et al. (2019). Synthesis and Biological Evaluation of Bergenin-1,2,3-Triazole Hybrids as Novel Class of Anti-mitotic Agents. Bioorg. Chem. 91, e103161. doi:10.1016/j. bioorg.2019.103161

Kumar, R. N., Dev, G. J., Ravikumar, N., Swaroop, D. K., Debanjan, B., Bjarath, G., et al. (2016). Synthesis of Novel Triazole/isoxazole Functionalized 7(trifluoromethyl)pyrido[2,3-D]pyrimidine Derivatives as Promising Anticancer and Antibacterial Agents. Bioorg. Med. Chem. Lett. 26, 2927-2930. doi:10.1016/j.bmcl.2016.04.038

Kummari, B., Polkam, N., Ramesh, P., Anantaraju, H., Yogeeswari, P., Anireddy, J. S., et al. (2017). Design and Synthesis of 1,2,3-TriazoleEtodolac Hybrids as Potent Anticancer Molecules. RSC Adv. 7, e23680. doi:10.1039/c6ra28525b

Kuntala, N., Telu, J. R., Banothu, V., Nallapati, S. B., Anireddy, J. S., and Pal, S. (2015). Novel Benzoxepine-1,2,3-Triazole Hybrids: Synthesis and Pharmacological Evaluation as Potential Antibacterial and Anticancer Agents. Med. Chem. Commun. 6, 1612-1619. doi:10.1039/c5md00224a

Lal, K., and Yadav, P. (2018). Recent Advancements in 1, 4-disubstituted 1H-1,2,3Triazoles as Potential Anticancer Agents. Anti-cancer Agents Med. Chem. 18 (1), 26-37. doi:10.2174/1871520616666160811113531

Lan, T. T., Anh, D. T., Hai, P.-T., Dung, D. T. M., Huong, L. T. T., Park, E. J., et al. (2020). Design, Synthesis, and Bioevaluation of Novel Oxoindolin-2-One Derivatives Incorporating 1-Benzyl-1H-1,2,3-Triazole. Med. Chem. Res. 29, 396-408. doi:10.1007/s00044-019-02488-1

Lan, T. T., Anh, D. T., Pham-The, H., Dung, T. M., Park, E. J., Jang, S. D., et al. (2020). Design, Synthesis and Bioevaluation of Two Series of 3-((1-Benzyl-1H1,2,3-Triazol-4-Yl)methyl)quinazolin-4(3H)-Ones and $N$-(1- Benzylpiperidin4-Yl)quinazolin-4-Amines. Chem. Biodiver. 17, e2000290. doi:10.1002/cbdv. 202000290
Le-Nhat-Thuy, G., Dinh, T. V., Pham-The, H., Nguyen Quang, H., Nguyen Thi, N., Dang Thi, T. A., et al. (2018). Design, Synthesis and Evaluation of Novel Hybrids between 4-anilinoquinazolines and Substituted Triazoles as Potent Cytotoxic Agents. Bioorg. Med. Chem. Lett. 28, 3741-3747. doi:10.1016/j.bmcl. 2018.10.016

Lee, S.-M., Yoon, K. B., Lee, H. J., Kim, J., Chung, Y. K., Cho, W.-J., et al. (2016). The Discovery of 2,5-isomers of Triazole-Pyrrolopyrimidine as Selective Janus Kinase 2 (JAK2) Inhibitors versus JAK1 and JAK3. Bioorg. Med. Chem. 24, 5036-5046. doi:10.1016/j.bmc.2016.08.008

Li, H.-n., Wang, H., Wang, Z.-p., Yan, H.-n., Zhang, M., Liu, Y., et al. (2018). Synthesis, Antitumor Activity Evaluation and Mechanistic Study of Novel Hederacolchiside A1 Derivatives Bearing an Aryl Triazole Moiety. Bioorg. Med. Chem. 26, 4025-4033. doi:10.1016/j.bmc.2018.06.026

Li, H.-T., and Zhu, X. (2021). Quinoline-based Compounds with Potential Activity against Drugresistant Cancers. Ctmc 21 (5), 426-437. doi:10.2174/ 1568026620666200618113957

Li, J. Q., and Han, X. (2016). Synthesis and Anti-tumor Activity of Novel Histone Deacetylase Inhibitors Based on Dihydropyridin-2-One Scaffold. Yao Xue Xue Bao 51, 1734-1744. doi:10.16438/J.0513-4870.2016-0503

Li, S., Li, X. Y., Zhang, T. J., Kamara, M. O., Liang, J. W., Zhu, J., et al. (2020). Design, Synthesis and Biological Evaluation of Homoerythrina Alkaloid Derivatives Bearing a Triazole Moiety as PARP-1 Inhibitors and as Potential Antitumor Drugs. Bioorg. Chem. 94, e103385. doi:10.1016/j.bioorg. 2019.103385

Li, S., Li, X. Y., Zhang, T. J., Zhu, J., Xue, W. H., Qian, X. H., et al. (2020). Design, Synthesis and Biological Evaluation of erythrina Derivatives Bearing a 1,2,3triazole Moiety as PARP-1 Inhibitors. Bioorg. Chem. 96, e103575. doi:10.1016/j. bioorg.2020.103575

Li, X., Wu, Y., Wang, Y., You, Q., and Zhang, X. (2017). 'Click Chemistry' Synthesis of Novel Natural Product-like Caged Xanthones Bearing a 1,2,3-triazole Moiety with Improved Druglike Properties as Orally Active Antitumor Agents. Molecules 22, e1834. doi:10.3390/molecules22111834

Li, Y., Shi, Q., Shao, J., Yuan, Y., Yang, Z., Chen, S., et al. (2018). Synthesis and Biological Evaluation of 20-Epi-Amino-20-Deoxysalinomycin Derivatives. Eur. J. Med. Chem. 148, 279-290. doi:10.1016/j.ejmech.2018.02.004

Liu, C.-F., Shen, Q.-K., Li, J.-J., Tian, Y.-S., and Quan, Z. (2017). Synthesis and Biological Evaluation of Novel 7-Hydroxy-4-Phenylchromen-2-One-Linked to Triazole Moieties as Potent Cytotoxic Agents. J. Enzyme Inhib. Med. Chem. 32 (1), 1111-1119. doi:10.1080/14756366.2017.1344982

Liu, M., Hou, Y., Yin, W., Zhou, S., Qian, P., Guo, Z., et al. (2016). Discovery of a Novel 6,7-Disubstituted-4-(2-Fluorophenoxy)quinolines Bearing 1,2,3Triazole-4-Carboxamide Moiety as Potent C-Met Kinase Inhibitors. Eur. J. Med. Chem. 119, 96-108. doi:10.1016/j.ejmech.2016.04.035

Lu, G.-q., Li, X.-y., Mohamed O, K., Wang, D., and Meng, F.-h. (2019). Design, Synthesis and Biological Evaluation of Novel Uracil Derivatives Bearing 1, 2, 3 triazole Moiety as Thymidylate Synthase (TS) Inhibitors and as Potential Antitumor Drugs. Eur. J. Med. Chem. 171, 282-296. doi:10.1016/j.ejmech. 2019.03.047

Lu, Y., Wang, L., Wang, X., Xi, T., Liao, J., Wang, Z., et al. (2017). Design, Combinatorial Synthesis and Biological Evaluations of Novel 3-Amino-1'-((1Aryl-1 H -1,2,3-Triazol-5-Yl)methyl)-2'-Oxospiro[benzo[ a ] Pyrano[2,3- C ] phenazine-1,3'-Indoline]-2-Carbonitrile Antitumor Hybrid Molecules. Eur. J. Med. Chem. 135, 125-141. doi:10.1016/j.ejmech.2017.04.040

Luan, T., Quan, Z., Fang, Y., and Yang, H. (2020). Design, Synthesis and Antiproliferative Activity of Chrysin Derivatives Bearing Triazole Moieties. Chin. J. Org. Chem. 40, 440-446. doi:10.6023/cjoc201907012

Macan, A. M., Harej, A., Cazin, I., Klobucar, M., Stepanic, V., Pavelic, K., et al. (2019). Antitumor and Antiviral Activities of 4-substituted 1,2,3-Triazolyl-2,3Dibenzyl-L-Ascorbic Acid Derivatives. Eur. J. Med. Chem. 184, e111739. doi:10. 1016/j.ejmech.2019.111739

Madasu, C., Karri, S., Sangaraju, R., Sistla, R., and Uppuluri, M. V. (2020). Synthesis and Biological Evaluation of Some Novel 1,2,3-triazole Hybrids of Myrrhanone B Isolated from Commiphora Mukul Gum Resin: Idenfication of Potent Antiproliferative Leads Active against Prostate Cancer Cells (PC-3). Eur. J. Med. Chem. 188, e111974. doi:10.1016/j.ejmech.2019.111974

Majem, B., Nadal, E., and Muñoz-Pinedo, C. (2020). Exploiting Metabolic Vulnerabilities of Non Small Cell Lung Carcinoma. Semin. Cel Develop. Biol. 98, 54-62. doi:10.1016/j.semcdb.2019.06.004 
Makarov, M. V., Rybalkina, E. Y., Khrustalev, V. N., and Röschenthaler, G.-V. (2015). Modification of 3,5-Bis(arylidene)-4-Piperidone Pharmacophore by Phosphonate Group Using 1,2,3-triazole Cycle as a Linker for the Synthesis of New Cytostatics. Med. Chem. Res. 24, 1753-1762. doi:10.1007/s00044-0141262-z

Manjinder, K., Swarandeep, K., Sonali, S., Yogita, B., and Gulshan, B. (2015). Coumarin: A Promising Scaffold for Anticancer Agents. Anti-cancer Agents Med. Chem. 15 (8), 1032-1048. doi:10.2174/1871520615666150101125503

Manvendra, K., Ramit, S., Jyoti, D., and Vikas, J. (2018). Coumarin Derivatives as Anticancer Agents for Lung Cancer Therapy: A Review. Anti-cancer Agents Med. Chem. 18 (7), 964-984. doi:10.2174/1871520618666171229185926

Mareddy, J., Suresh, N., Kumar, C. G., Kapavarapu, R., Jayasree, A., and Pal, S. (2017). 1,2,3-Triazole-nimesulide Hybrid: Their Design, Synthesis and Evaluation as Potential Anticancer Agents. Bioorg. Med. Chem. Lett. 27, 518-523. doi:10.1016/j.bmcl.2016.12.030

Masood-Ur-Rahman, M., Mohammad, Y., Fazili, K. M., Bhat, K. A., and Ara, T. (2017). Synthesis and Biological Evaluation of Novel 3-O-Tethered Triazoles of Diosgenin as Potent Antiproliferative Agents. Steroids 118, 1-8. doi:10.1016/j. steroids.2016.11.003

Mo, S., Ding, Y., Zhang, G., Zhang, Z., Shao, X., Li, Q., et al. (2017). Synthesis and Anti-tumor Activity Evaluation of a Novel Series of Dithiocarbamates Bearing 1,2,3-triazole and [1-Bi(4-Fluorophenyl)methyl]piperazine Unit. Chin. J. Org. Chem. 37, 1000-1008. doi:10.6023/cjoc201611039

Murugavel, S., Ravikumar, C., Jaabil, G., and Alagusundaram, P. (2019). Synthesis, Computational Quantum Chemical Study, In Silico ADMET and Molecular Docking Analysis, In Vitro Biological Evaluation of a Novel Sulfur Heterocyclic Thiophene Derivative Containing 1,2,3-triazole and Pyridine Moieties as a Potential Human Topoisomerase II $\alpha$ Inhibiting Anticancer Agent. Comput. Biol. Chem. 79, 73-82. doi:10.1016/j.compbiolchem.2019.01.013

Murugavel, S., Ravikumar, C., Jaabil, G., and Alagusundaram, P. (2019). Synthesis, crystal Structure Analysis, Spectral Investigations (NMR, FT-IR, UV), DFT Calculations, ADMET Studies, Molecular Docking and Anticancer Activity of 2-(1-Benzyl-5-Methyl-1H-1,2,3-Triazol-4-Yl)-4-(2-Chlorophenyl)-6-

Methoxypyridine - A Novel Potent Human Topoisomerase IIa Inhibitor. J. Mol. Struct. 1176, 729-742. doi:10.1016/j.molstruc.2018.09.010

Nagarsenkar, A., Guntuku, L., Guggilapu, S. D., K., D. B., Gannoju, S., Naidu, V. G. M., et al. (2016). Synthesis and Apoptosis Inducing Studies of Triazole Linked 3-benzylidene Isatin Derivatives. Eur. J. Med. Chem. 124, 782-793. doi:10.1016/ j.ejmech.2016.09.009

Nagarsenkar, A., Prajapti, S. K., Guggilapu, S. D., Birineni, S., Sravanti Kotapalli, S., Ummanni, R., et al. (2016). Investigation of Triazole-Linked Indole and Oxindole Glycoconjugates as Potential Anticancer Agents: Novel Akt/PKB Signaling Pathway Inhibitors. Med. Chem. Commun. 7, 646-653. doi:10.1039/ c5md00513b

Narsimha, S., Battula, K. S., Reddy, Y. N., and Nagavelli, V. R. (2018). Microwaveassisted Cu-Catalyzed C-C Bond Formation: One-Pot Synthesis of Fully Substituted 1,2,3-triazoles Using Nonsymmetrical Iodoalkynes and Their Biological Evaluation. Chem. Heterocycl Comp. 54 (12), 1161-1167. doi:10. 1007/s10593-019-02408-6

Narva, S., Chitti, S., Bala, B. R., Alvala, M., Jain, N., and Kondapalli, V. G. C. S. (2016). Synthesis and Biological Evaluation of Pyrrolo[2,3- B ]pyridine Analogues as Antiproliferative Agents and Their Interaction with Calf Thymus DNA. Eur. J. Med. Chem. 114, 220-231. doi:10.1016/j.ejmech.2016. 02.059

Nasim, F., Sabath, B. F., and Eapen, G. A. (2019). Lung Cancer. Med. Clin. North America 103 (3), 463-473. doi:10.1016/j.mcna.2018.12.006

Nguyen, B. C. Q., Takahashi, H., Uto, Y., Shahinozzaman, M. d., Tawata, S., and Maruta, H. (2017). 1,2,3-Triazolyl Ester of Ketorolac: A "Click Chemistry"Based Highly Potent PAK1-Blocking Cancer-Killer. Eur. J. Med. Chem. 126, 270-276. doi:10.1016/j.ejmech.2016.11.038

Nordstrøm, L. U., Sironi, J., Aranda, E., Maisonet, J., Perez-Soler, R., Wu, P., et al. (2015). Discovery of Autophagy Inhibitors with Antiproliferative Activity in Lung and Pancreatic Cancer Cells. ACS Med. Chem. Lett. 6, 134-139. doi:10. $1021 / \mathrm{ml} 500348 \mathrm{p}$

Oliveira-Pinto, S., Pontes, O., Baltazar, F., and Costa, M. (2020). In Vivo efficacy Studies of Chromene-Based Compounds in Triple-Negative Breast Cancer - A Systematic Review. Eur. J. Pharmacol. 887, e173452. doi:10.1016/j.ejphar.2020. 173452
Ou, Z., Li, Z., Gao, Y., Xing, W., Jia, H., Zhang, H., et al. (2019). Novel Triazole and Morpholine Substituted Bisnaphthalimide: Synthesis, Photophysical and G-Quadruplex Binding Properties. J. Mol. Struct. 1185, 27-37. doi:10.1016/j. molstruc.2019.02.073

Pan, S., Zhou, Y., Wang, Q., Wang, Y., Tian, C., Wang, T., et al. (2020). Discovery and Structure-Activity Relationship Studies of 1-Aryl-1H-Naphtho[2,3-D] $[1,2,3]$ triazole-4,9-Dione Derivatives as Potent Dual Inhibitors of Indoleamine 2,3-dioxygenase 1 (IDO1) and Trytophan 2,3-dioxygenase (TDO). Eur. J. Med. Chem. 207, e112703. doi:10.1016/j.ejmech.2020.112703

Pan, X., Liang, L., Si, R., Wang, J., Zhang, Q., Zhou, H., et al. (2019). Discovery of Novel Anti-angiogenesis Agents. Part 10: Multi-Target Inhibitors of VEGFR-2, Tie-2 and EphB4 Incorporated with 1,2,3-triazol. Eur. J. Med. Chem. 163, 1-9. doi:10.1016/j.ejmech.2018.11.042

Patil, S. B. (2018). Biological and Medicinal Significance of Pyrimidines: A Review. Int. J. Pharm. Sci. Res. 9 (1), 44-52. doi:10.13040/IJPSR.0975-8232

Petrova, K. T., Potewar, T. M., Correia-da-Silva, P., Barros, M. T., Calhelha, R. C., Ćiric, A., et al. (2015). Antimicrobial and Cytotoxic Activities of 1,2,3-TriazoleSucrose Derivatives. Carbohydr. Res. 417, 66-71. doi:10.1016/j.carres.2015. 09.003

Podolski-Renic, A., Bosze, S., Dinic, J., Kocsis, L., Hudecz, F., Csampai, A., et al. (2017). Ferrocene-cinchona Hybrids with Triazolyl-Chalcone Linker Act as Pro-oxidants and Sensitize Human Cancer Cell Lines to Paclitaxel. Metallomics 9, 1132-1142. doi:10.1039/c7mt00183e

Poornima, B., Siva, B., Shankaraiah, G., Venkanna, A., Nayak, V. L., Ramakrishna, S., et al. (2015). Novel Sesquiterpenes from Schisandra Grandiflora: Isolation, Cytotoxic Activity and Synthesis of Their Triazole Derivatives Using "Click" Reaction. Eur. J. Med. Chem. 92, 449-458. doi:10.1016/j.ejmech.2014.12.040

Popov, S. A., Semenova, M. D., Baev, D. S., Frolova, T. S., Shestopalov, M. A., Wang, C., et al. (2020). Synthesis and Cytotoxicity of Hybrids of 1,3,4- or 1,2,5oxadiazoles Tethered from Ursane and Lupane Core with 1,2,3-triazole. Steroids 162, e108698. doi:10.1016/j.steroids.2020.108698

Prachayasittikul, S., Pingaew, R., Worachartcheewan, A., Sinthupoom, N., Prachayasittikul, V., Ruchirawat, S., et al. (2017). Roles of Pyridine and Pyrimidine Derivatives as Privileged Scaffolds in Anticancer Agents. Minirev. Med. Chem. 17, 869-901. doi:10.2174/1389557516666160923125801

Prasad, B., Lakshma Nayak, V., Srikanth, P. S., Baig, M. F., Subba Reddy, N. V., Babu, K. S., et al. (2019). Synthesis and Biological Evaluation of 1-Benzyl-N-(2(phenylamino)pyridin-3-Yl)-1H-1,2,3-Triazole-4-Carboxamides as Antimitotic Agents. Bioorg. Chem. 83, 535-548. doi:10.1016/j.bioorg.2018.11.002

Prasad, C. V., Nayak, V. L., Ramakrishna, S., and Mallavadhani, U. V. (2018). Novel Menadione Hybrids: Synthesis, Anticancer Activity, and Cell-Based Studies. Chem. Biol. Drug Des. 91, 220-233. doi:10.1111/cbdd.13073

Praveen Kumar, C., Reddy, T. S., Mainkar, P. S., Bansal, V., Shukla, R., Chandrasekhar, S., et al. (2016). Synthesis and biological evaluation of 5,10dihydro-11H-dibenzo[b,e][1,4] diazepin-11-one structural derivatives as anticancer and apoptosis inducing agents. Eur. J. Med. Chem. 108, 674-686. doi:10. 1016/j.ejmech.2015.12.007

Praveena, K. S. S., Ramarao, E. V. V. S., Poornachandra, Y., Kumar, C. G., Babu, N. S., Murthy, N. Y. S., et al. (2016). Assembly of Quinoline, Triazole and Oxime Ether in a Single Molecular Entity: A Greener and One-Pot Synthesis of Novel Oximes as Potential Cytotoxic Agents. Lett. Drug Des. Discov. 13, 210-219. doi:10.2174/1570180812999150819095308

Qi, Z. Y., Hao, S. Y., Tian, H. Z., Bian, H. L., Hui, L., and Chen, S. W. (2020). Synthesis and Biological Evaluation of 1-(benzofuran-3-Yl)-4-(3,4,5Trimethoxyphenyl)-1H-1,2,3-Triazole Derivatives as Tubulin Polymerization Inhibitors. Bioorg. Chem. 94, e103392. doi:10.1016/j.bioorg.2019.103392

Qiao, J., Lin, G., Xia, A., Xiang, Z., Chen, P., Zhang, G., et al. (2019). Discovery of 1,8 -Disubstituted-[1,2,3] triazolo[4,5-C]quinoline Derivatives as a New Class of Hippo Signaling Pathway Inhibitors. Bioorg. Med. Chem. Lett. 29, 2595-2603. doi:10.1016/j.bmcl.2019.08.001

Rachakonda, V., Kotapalli, S. S., Ummanni, R., and Alla, M. (2017). Ring Functionalization and Molecular Hybridization of Quinolinyl Pyrazole: Design, Synthesis and Antimycobacterial Activity. ChemistrySelect 2, 6529-6534. doi:10.1002/slct.201701241

Raghavender, M., Kumar, A. K., Sunitha, V., Vishnu, T., and Jalapathi, P. (2020). Synthesis and Cytotoxicity of Chalcone Based 1,2,3-triazole Derivatives. Russ. J. Gen. Chem. 90 (4), 697-702. doi:10.1134/ s1070363220040210 
Rani, A., Singh, G., Singh, A., Maqbool, U., Kaur, G., and Singh, J. (2020). CuAACensembled 1,2,3-Triazole-Linked Isosteres as Pharmacophores in Drug Discovery: Review. RSC Adv. 10 (10), 5610-5635. doi:10.1039/c9ra09510a

Reddy, K. S. N., Sabitha, G., Poornachdra, Y., and Kumar, C. G. (2016). Synthesis and Biological Evaluation of Sapinofuranones A,B and 1,2,3-TriazoleSapinofuranone Hybrids as Cytotoxic Agents. RSC Adv. 6, 101501-101509. doi:10.1039/C6RA21939J

Reddy, V. G., Bonam, S. R., Reddy, T. S., Akunuri, R., Naidu, V. G. M., Nayak, V. L., et al. (2018). $4 \beta$-amidotriazole Linked Podophyllotoxin Congeners: DNA Topoisomerase-II $\alpha$ Inhibition and Potential Anticancer Agents for Prostate Cancer. Eur. J. Med. Chem. 144, 595-611. doi:10.1016/j.ejmech.2017.12.050

Robak, T. (2011). New Nucleoside Analogs for Patients with Hematological Malignancies. Expert Opin. Investig. Drugs 20 (3), 343-359. doi:10.1517/ 13543784.2011.554822

Rono, C. K., Darkwa, J., Meyer, D., and Makhubela, B. C. E. (2019). A Novel Series of $\mathrm{N}$-Aryltriazole and $\mathrm{N}$-Acridinyltriazole Hybrids as Potential Anticancer Agents. Cos 16, 900-912. doi:10.2174/1570179416666190704112904

Routh, S., and Nandagopal, K. (2017). Patent Survey of Resveratrol, Taxol, Podophyllotoxin, Withanolides and Their Derivatives Used in Anticancer Therapy. Recent Pat. Biotechnol. 11 (2), 85-100. doi:10.2174/ 1872208311666170127114804

Ruddarraju, R. R., Murugulla, A. C., Kotla, R., Tirumalasetty, M. C. B., Wudayagiri, R., Donthabakthuni, S., et al. (2016). Design, Synthesis, Anticancer, Antimicrobial Activities and Molecular Docking Studies of Theophylline Containing Acetylenes and Theophylline Containing 1,2,3-triazoles with Variant Nucleoside Derivatives. Eur. J. Med. Chem. 123, 279-296. doi:10. 1016/j.ejmech.2016.07.024

Ruddarraju, R. R., Murugulla, A. C., Kotla, R., Tirumalasetty, M. C. B., Wudayagiri, R., Donthabakthuni, S., et al. (2017). Design, Synthesis, Anticancer Activity and Docking Studies of Theophylline Containing 1,2,3-triazoles with Variant Amide Derivatives. Med. Chem. Commun. 8, 176-183. doi:10.1039/ c6md00479b

Safavi, M., Ashtari, A., Khalili, F., Mirfazli, S. S., Saeedi, M., Ardestani, S. K., et al. (2018). Novel quinazolin-4(3H )-one Linked to 1,2,3-triazoles: Synthesis and Anticancer Activity. Chem. Biol. Drug Des. 92, 1373-1381. doi:10.1111/cbdd. 13203

Sahu, A., Sahu, P., and Agrawal, R. (2020). A Recent Review on Drug Modification Using 1,2,3-triazole. Ccb $14 \quad$ (2), 71-87. doi:10.2174/ 2212796814999200807214519

Salehi, M., Movahedpour, A., Tayarani, A., Shabaninejad, Z., Pourhanifeh, M. H., Mortezapour, E., et al. (2020). Therapeutic Potentials of Curcumin in the Treatment of Non-small-cell Lung Carcinoma. Phytotherapy Res. 34 (10), 2557-2576. doi:10.1002/ptr.6704

Sanduja, M., Gupta, J., Singh, H., Pagare, P. P., and Rana, A. (2020). Uracilcoumarin Based Hybrid Molecules as Potent Anti-cancer and Anti-bacterial Agents. J. Saudi Chem. Soc. 24, 251-266. doi:10.1016/j.jscs.2019.12.001

Sathish, M., Kavitha, B., Nayak, V. L., Tangella, Y., Ajitha, A., Nekkanti, S., et al. (2018). Synthesis of Podophyllotoxin Linked $\beta$-carboline Congeners as Potential Anticancer Agents and DNA Topoisomerase II Inhibitors. Eur. J. Med. Chem. 144, 557-571. doi:10.1016/j.ejmech.2017.12.055

Sayeed, I. B., Vishnuvardhan, M. V. P. S., Nagarajan, A., Kantevari, S., and Kamal, A. (2018). Imidazopyridine Linked Triazoles as Tubulin Inhibitors, Effectively Triggering Apoptosis in Lung Cancer Cell Line. Bioorg. Chem. 80, 714-720. doi:10.1016/j.bioorg.2018.07.026

Senwar, K. R., Sharma, P., Reddy, T. S., Jeengar, M. K., Nayak, V. L., Naidu, V. G. M., et al. (2015). Spirooxindole-derived Morpholine-Fused-1,2,3-Triazoles: Design, Synthesis, Cytotoxicity and Apoptosis Inducing Studies. Eur. J. Med. Chem. 102, 413-424. doi:10.1016/j.ejmech.2015.08.017

Shaikh, M. H., Subhedar, D. D., Arkile, M., Khedkar, V. M., Jadhav, N., Sarkar, D., et al. (2016). Synthesis and Bioactivity of Novel Triazole Incorporated Benzothiazinone Derivatives as Antitubercular and Antioxidant Agent. Bioorg. Med. Chem. Lett. 26, 561-569. doi:10.1016/ j.bmcl.2015.11.071

Shamsi, F., Aneja, B., Hasan, P., Zeya, B., Zafaryab, M., Mehdi, S. H., et al. (2019). Synthesis, Anticancer Evaluation and DNA-Binding Spectroscopic Insights of Quinoline-Based 1,3,4-Oxadiazole-1,2,3-triazole Conjugates. ChemistrySelect 4, 12176-12182. doi:10.1002/slct.201902797
Shamsiya, A., and Damodaran, B. (2019). A Click Strategy for the Synthesis of Fluorescent Pyrimidinone-Triazole Hybrids with CDK2 Selectivity in HeLa and A549 Cell Lines. ChemistrySelect 4, 3076-3082. doi:10.1002/slct. 201803748

Sharma, S., Gupta, M. K., Saxena, A. K., and Bedi, P. M. S. (2015). Triazole Linked Mono Carbonyl Curcumin-Isatin Bifunctional Hybrids as Novel Anti Tubulin Agents: Design, Synthesis, Biological Evaluation and Molecular Modeling Studies. Bioorg. Med. Chem. 23, 7165-7180. doi:10.1016/j.bmc.2015.10.013

Silalai, P., Sirion, U., Piyachaturawat, P., Chairoungdua, A., Suksen, K., and Saeeng, R. (2020). Design, Synthesis and Evaluations of New 10-Triazolyl-1methoxygenipin Analogues for Their Cytotoxicity to Cancer Cells. ChemistrySelect 5, 9540-9546. doi:10.1002/slct.202001908

Slavova, K. I., Todorov, L. T., Belskaya, N. P., Palafox, M. A., and Kostova, I. P. (2020). Developments in the Application of 1,2,3-Triazoles in Cancer Treatment. Recent Pat. Anticancer Drug Discov. 15 (2), 92-112. doi:10.2174/ 1574892815666200717164457

Srinivas, S., Neeraja, P., Naveen, K., Banothu, V., Dubey, P. K., Mukkanti, K., et al. (2020). Synthesis, Chemotherapeutic Screening and Docking Studies of NSAID Inserted Peptide-Triazole Hybrid Molecules. ChemistrySelect 5, 6786-6791. doi:10.1002/slct.202000492

Sudhapriya, N., Nandakumar, A., Arun, Y., Perumal, P. T., Balachandran, C., and Emi, N. (2015). An Expedient Route to Highly Diversified [1,2,3]triazolo[1,5-A] [1,4]benzodiazepines and Their Evaluation for Antimicrobial, Antiproliferative and In Silico Studies. RSC Adv. 5, 66260-66270. doi:10.1039/c5ra12497b

Suryapeta, S., Papigani, N., Banothu, V., Dubey, P. K., Mukkanti, K., and Pal, S. (2020). Synthesis, Biological Evaluation, and Docking Study of a Series of 1,4disubstituted 1,2,3-triazole Derivatives with an Indole-triazole-peptide Conjugate. J. Heterocyclic Chem. 57, 3126-3141. doi:10.1002/jhet.4020

Tang, Q., Wang, L., Tu, Y., Zhu, W., Luo, R., Tu, Q., et al. (2016). Discovery of Novel Pyrrolo[2,3-B]pyridine Derivatives Bearing 1,2,3-triazole Moiety as C-Met Kinase Inhibitors. Bioorg. Med. Chem. Lett. 26, 1680-1684. doi:10. 1016/j.bmcl.2016.02.059

Tantawy, M. A., Nafie, M. S., Elmegeed, G. A., and Ali, I. A. I. (2017). Auspicious Role of the Steroidal Heterocyclic Derivatives as a Platform for Anti-cancer Drugs. Bioorg. Chem. 73, 128-146. doi:10.1016/j.bioorg.2017.06.006

Tapadar, S., Fathi, S., Raji, I., Omesiete, W., Kornacki, J. R., Mwakwari, S. C., et al. (2015). A Structure-Activity Relationship of Non-peptide Macrocyclic Histone Deacetylase Inhibitors and Their Anti-proliferative and Anti-inflammatory Activities. Bioorg. Med. Chem. 23, 7543-7564. doi:10.1016/j.bmc.2015.10.045

Theeramunkong, S., Vajragupta, O., and Mudjupa, C. (2016). Synthesis and Biological Evaluation of Simplified Analogs of Lophocladine B as Potential Antitumor Agents. Med. Chem. Res. 25, 2959-2964. doi:10.1007/s00044-0161717-5

Thomopoulou, P., Sachs, J., Teusch, N., Mariappan, A., Gopalakrishnan, J., and Schmalz, H.-G. (2016). New Colchicine-Derived Triazoles and Their Influence on Cytotoxicity and Microtubule Morphology. ACS Med. Chem. Lett. 7, 188-191. doi:10.1021/acsmedchemlett.5b00418

Treyakova, E. V., Salimova, E. V., and Parfenova, L. V. (2020). Synthesis, Modification, and Biological Activity of Propargylated Methyl Dihydroquinopimarates. Nat. Prod. Res. doi:10.1080/14786419.2020.1762187

Trznadel, R., Singh, A., Kleczewska, N., Liberska, J., Ruszkowski, P., and Celewicz, L. (2019). Synthesis and In Vitro Anticancer Activity of New GemcitabineNucleoside Analogue Dimers Containing Methyltriazole or EsterMethyltriazole Linker. Bioorg. Med. Chem. Lett. 29, 2587-2594. doi:10.1016/ j.bmcl.2019.08.003

Tsai, Y. H., Etichetti, C. M. B., Cicetti, S., Girardini, J. E., Spanevello, R. A., Suarez, A. G., et al. (2020). Design, Synthesis and Evaluation of Novel Levoglucosenone Derivatives as Promising Anticancer Agents. Bioorg. Med. Chem. Lett. 30, e127247. doi:10.1016/j.bmcl.2020.127247

Vanaparthi, S., Bantu, R., Jain, N., Janardhan, S., and Nagarapu, L. (2020). Synthesis and Anti-proliferative Activity of a Novel 1,2,3-triazole Tethered Chalcone Acetamide Derivatives. Bioorg. Med. Chem. Lett. 30, e127304. doi:10. 1016/j.bmcl.2020.127304

Vasu, K. K., Ingawale, H. D., Sagar, S. R., Sharma, J. A., Pandya, D. H., and Agarwal, M. (2018). 2-((1H-1,2,3-triazol-1-yl)methyl)-3-phenylquinazolin-4(3H)-ones: Design, Synthesis and Evaluation as Anti-cancer Agents. Cbc 14, 254-263. doi:10.2174/1573407213666170329131557 
Wang, L., Liu, X., Duan, Y., Li, X., Zhao, B., Wang, C., et al. (2018). Discovery of Novel Pyrrolopyrimidine/pyrazolopyrimidine Derivatives Bearing 1,2,3triazole Moiety as C-Met Kinase Inhibitors. Chem. Biol. Drug Des. 92, 1301-1314. doi:10.1111/cbdd.13192

Wang, L., Xu, S., Liu, X., Chen, X., Xiong, H., Hou, S., et al. (2018). Discovery of Thinopyrimidine-Triazole Conjugates as C-Met Targeting and Apoptosis Inducing Agents. Bioorg. Chem. 77, 370-380. doi:10.1016/j.bioorg.2018.01.037

Wang, Y., Chen, S., Hu, G., Wang, J., Gou, W., Zuo, D., et al. (2018). Discovery of Novel 2,4-diarylaminopyrimidine Analogues as ALK and ROS1 Dual Inhibitors to Overcome Crizotinib-Resistant Mutants Including G1202R. Eur. J. Med. Chem. 143, 123-136. doi:10.1016/j.ejmech.2017.11.008

Willis, C., Fiander, M., Tran, D., Korytowsky, B., Thomas, J.-M., Calderon, F., et al. (2019). Tumor Mutational burden in Lung Cancer: A Systematic Literature Review. Oncotarget 10 (61), 6604-6622. doi:10.18632/oncotarget.27287

Wu, J., Dai, J., Zhang, Y., Wang, J., Huang, L., Ding, H., et al. (2019). Synthesis of Novel Xanthone Analogues and Their Growth Inhibitory Activity against Human Lung Cancer A549 Cells. Dddt 13, 4239-4246. doi:10.2147/dddt. s217827

Xiao, J., Gao, M., Sun, Z., Diao, Q., Wang, P., and Gao, F. (2020). Recent Advances of Podophyllotoxin/epipodophyllotoxin Hybrids in Anticancer Activity, Mode of Action, and Structure-Activity Relationship: An Update (2010-2020). Eur. J. Med. Chem. 208, e112830. doi:10.1016/j.ejmech.2020.112830

Xiao, J., Gao, M., Fei, B., Huang, G., and Diao, Q. (2020). Nature-derived Anticancer Steroids outside Cardica Glycosides. Fitoterapia 147, e104757. doi:10.1016/j.fitote.2020.104757

Xiong, H., Cheng, J., Zhang, J., Zhang, Q., Xiao, Z., Zhang, H., et al. (2020). Design, Synthesis, and Biological Evaluation of Pyridineamide Derivatives Containing a 1,2,3-triazole Fragment as Type II C-Met Inhibitors. Molecules 25 (10), e3390. doi:10.3390/molecules 25010010

$\mathrm{Xu}, \mathrm{D}$., and $\mathrm{Xu}, \mathrm{Z}$. (2020). Indole Alkaloids with Potential Anticancer Activity. Ctmc 20 (21), 1938-1949. doi:10.2174/1568026620666200622150325

Xu, Z. (2020). 1,2,3-Triazole-containing Hybrids with Potential Antibacterial Activity against Methicillin-Resistant Staphylococcus aureus (MRSA). Eur. J. Med. Chem. 206, e112686. doi:10.1016/j.ejmech.2020.112686

Wang, R., Yin, X., Zhang, Y., Zhang, T., and Shi, W. (2018). Design, Synthesis, and In Vitro Anti-tumor Activities of 1,2,3-triazoletetraethylene Glycol Tethered Heteronuclear Bis-Schiff Base Derivatives of Isatin. J. Heterocyclic Chem. 55, 3001-3005. doi:10.1002/jhet.3341

Xu, Z., Zhao, S. J., and Liu, Y. (2019). 1,2,3-Triazole-containing Hybrids as Potential Anticancer Agents: Current Developments, Action Mechanisms and Structure-Activity Relationships. Eur. J. Med. Chem. 183, e111700. doi:10.1016/j.ejmech.2019.111700

Xu, Z., Zhao, S. J., Lv, Z. S., Gao, F., Wang, Y. L., Zhang, F., et al. (2019). Design, Synthesis, and Evaluation of Tetraethylene Glycol-Tethered Isatin-1,2,3Triazole-Coumarin Hybrids as Novel Anticancer Agents. J. Heterocyclic Chem. 56, 1127-1132. doi:10.1002/jhet.3475

Yadav, P., Lal, K., Kumar, A., Guru, S. K., Jaglan, S., and Bhushan, S. (2017). Green Synthesis and Anticancer Potential of Chalcone Linked-1,2,3-Triazoles. Eur. J. Med. Chem. 126, 944-953. doi:10.1016/j.ejmech.2016.11.030

Yakantham, T., Sreenivasulu, R., Alluraiah, G., Tej, M. B., and Ramesh Raju, R. (2019). Design, Synthesis, and Anticancer Activity of 1,2,3-triazole Likned Thiazole-1,2-Isoxazole Derivatives. Russ. J. Gen. Chem. 89 (12), 2522-2527. doi:10.1134/s1070363219120314

Yan, M., Xu, L., Wang, Y., Wan, J., Liu, T., Liu, W., et al. (2020). Opportunities and Challenges of Using Five-membered Ring Compounds as Promising Antitubercular Agents. Drug Dev. Res. 81 (4), 402-418. doi:10.1002/ddr. 21638

Yang, M., Liu, H., Zhang, Y., Wang, X., and Xu, Z. (2020). Moxifloxacin-isatin Hybrids Tethered by 1,2,3-triazole and Their Anticancer Activities. Ctmc 20 (16), 1461-1467. doi:10.2174/1568026620666200128144825

Yang, T., Shi, X., Guo, L., Gu, S., Zhang, W., Xu, G., et al. (2019). Design, Synthesis, and Antitumor Activity of Novel Paeonol Derivatives Containing the 1,4- benzoxazinone and 1,2,3-triazole Moieties. J. Chem. Res. 43, 241-247. doi:10. $1177 / 1747519819857479$

Zeng, D.-Y., Kuang, G.-T., Wang, S.-K., Peng, W., Lin, S.-L., Zhang, Q., et al. (2017). Discovery of Novel 11-triazole Substituted Benzofuro[3,2-B]quinolone Derivatives as $C-M y c$ G-Quadruplex Specific Stabilizers via Click Chemistry. J. Med. Chem. 60, 5407-5423. doi:10.1021/acs.jmedchem.7b00016

Zhang, B. (2019). Comprehensive Review on the Anti-bacterial Activity of 1,2,3triazole Hybrids. Eur. J. Med. Chem. 168, 357-372. doi:10.1016/j.ejmech.2019. 02.055

Zhang, H.-J., Zhang, G.-R., Piao, H.-R., and Quan, Z.-S. (2018). Synthesis and Characterisation of Celastrol Derivatives as Potential Anticancer Agents. J. Enzyme Inhib. Med. Chem. 33 (1), 190-198. doi:10.1080/14756366.2017. 1404590

Zhang, S., Xu, Z., Gao, C., Ren, Q.-C., Chang, L., Lv, Z.-S., et al. (2017). Triazole Derivatives and Their Anti-tubercular Activity. Eur. J. Med. Chem. 138, 501-513. doi:10.1016/j.ejmech.2017.06.051

Zhang, T., Li, Y., Zhang, H., Wang, X., Liu, X., and Li, L. (2020). The Role of RASSF1 Methylation in Lung Carcinoma. Adv. Exp. Med. Biol. 1255, 99-108. doi:10.1007/978-981-15-4494-1_8

Zhang, Y., Meng, X., Tang, H., Cheng, M., Yang, F., and Xu, W. (2020). Design, Synthesis, and Biological Evaluation of Novel Substituted Thiourea Derivatives as Potential Anticancer Agents for NSCLC by Blocking K-Ras Protein-Effectors Interactions. J. Enzyme Inhib. Med. Chem. 35 (1), 344-353. doi:10.1080/ 14756366.2019.1702653

Zhao, L., Mao, L., Hong, G., Yang, X., and Liu, T. (2015). Design, Synthesis and Anticancer Activity of Matrine-1H-1,2,3-Triazole-Chalcone Conjugates. Bioorg. Med. Chem. Lett. 25, 2540-2544. doi:10.1016/j.bmcl.2015.04.051

Zhu, R. X., Zhao, L., Zhang, Y. K., Luo, P., Liu, S. H., and Wang, J. G. (2015). Sequential Treatment with Ursolic Acid Chlorophenyl Triazole Followed by 5fluorouracil Shows Synergistic Activity in Small Cell Lung Cancer Cells. Bangladesh J. Pharmacol. 10, 197-204. doi:10.3329/bjp.v10i1.21641

Zi, C.-T., Li, G.-T., Li, Y., Zhou, J., Ding, Z.-T., Jiang, Z.-H., et al. (2015). Synthesis and Anticancer Activity of $4 \beta$-Triazole-Podophyllotoxin Glycosides. Nat. Prod. Bioprospect. 5, 83-90. doi:10.1007/s13659-015-0057-3

Zi, C.-T., Liu, Z.-H., Li, G.-T., Li, Y., Zhou, J., Ding, Z.-T., et al. (2015). Design, Synthesis, and Cytotoxicity of Perbutyrylated Glycosides of $4 \beta$ Triazolopodophyllotoxin Derivatives. Molecules 20, 3255-3280. doi:10.3390/ molecules 20023255

Zi, C.-T., Yang, L., Gao, W., Li, Y., Zhou, J., Ding, Z.-T., et al. (2017). Click Glycosylation for the Synthesis of 1,2,3-Triazole-Linked Picropodophyllotoxin Glycoconjugates and Their Anticancer Activity. ChemistrySelect 2, 5038-5044. doi:10.1002/slct.201700347

Zi, C.-T., Yang, L., Xu, F.-Q., Dong, F.-W., Yang, D., Li, Y., et al. (2018). Synthesis and Anticancer Activity of Dimeric Podophyllotoxin Derivatives. Dddt 12, 3393-3406. doi:10.2147/dddt.s167382

Zi, C. T., Sun, P. Y., Zhang, N., Tang, H., Yang, H. N., Wang, Q., et al. (2020). Synthesis of (-)-Epigallocatechin-3-Gallate Derivative Containing a Triazole Ring and Combined with Cisplatin/paclitaxel Inhibits NSCLC Cancer Cells by Decreasing Phosphorylation of the EGFR. J. Chem. Res. 44, 44-49. doi:10.1177/ 1747519820910390

Conflict of Interest: The authors declare that the research was conducted in the absence of any commercial or financial relationships that could be construed as a potential conflict of interest.

Copyright (C) 2021 Liang, Sun, Li, Hou and Gao. This is an open-access article distributed under the terms of the Creative Commons Attribution License (CC BY). The use, distribution or reproduction in other forums is permitted, provided the original author(s) and the copyright owner(s) are credited and that the original publication in this journal is cited, in accordance with accepted academic practice. No use, distribution or reproduction is permitted which does not comply with these terms. 